Geochimica et Cosmochimica Acta

September 2016, Volume 189, Pages 214-235

http://dx.doi.org/10.1016/i.gca.2016.06.005

http://archimer.ifremer.fr/doc/00341/45255/

(C) 2016 Elsevier Ltd. All rights reserved.

\title{
Comparative geochemistry of four ferromanganese crusts from the Pacific Ocean and significance for the use of $\mathrm{Ni}$ isotopes as paleoceanographic tracers
}

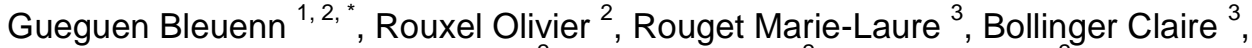 \\ Ponzevera Emmanuel ${ }^{2}$, Germain Yoan ${ }^{2}$, Fouquet Yves ${ }^{2}$
}

\footnotetext{
${ }^{1}$ Institut Universitaire Européen de la Mer, UMR 6538, Université de Bretagne Occidentale, 29280

Plouzané, France

2 IFREMER, Centre de Brest, Unité Géosciences Marines, 29280 Plouzané, France

${ }^{3}$ Institut Universitaire Européen de la Mer, UMS 3113, Université de Bretagne Occidentale, 29280

Plouzané, France

* Corresponding author : Bleuenn Gueguen, email address : $\underline{\text { bleuenn.gueguen@univ-brest.fr }}$
}

\begin{abstract}
:
Ferromanganese (Fe-Mn) crusts are potential archive of the $\mathrm{Ni}$ isotope composition of seawater through time. In this study we aim at (1) understanding $\mathrm{Ni}$ isotope fractionation mechanisms and metal enrichment processes in Fe-Mn deposits, (2) addressing global vs. local control of $\mathrm{Ni}$ isotope composition of these deposits. Two Fe-Mn crusts from the North Pacific Ocean (Apuupuu Seamount, Hawaii) and two Fe-Mn crusts from the South Pacific Ocean (near Rurutu Island, Austral archipelago of French Polynesia) were characterized for their elemental geochemistry and $\mathrm{Ni}$ isotope composition. Geochemical analyses were performed at millimeter intervals in order to provide time-resolved record of $\mathrm{Ni}$ isotopes. Chronology and growth rates were determined using cosmogenic $10 \mathrm{Be}$ isotope abundances. The results show that, despite different growth rates, textures and geochemical patterns, $\mathrm{Fe}-\mathrm{Mn}$ crusts from both North and South Pacific Oceans have fairly homogenous $\mathrm{Ni}$ isotope compositions over the last $\sim 17 \mathrm{Ma}$, yielding average $\delta 60 / 58 \mathrm{Ni}$ values of $1.79 \pm 0.21 \%$ o $(2 \mathrm{sd}, \mathrm{n}=31)$ and $1.73 \pm 0.21 \%$ o ( $2 \mathrm{sd}, \mathrm{n}=21$ ) respectively. In one crust sample, however, layers directly in contact with the altered substrate show anomalously light $\delta 60 / 58 \mathrm{Ni}$ values down to $0.25 \pm 0.05 \%$ (2se) together with rejuvenated $10 \mathrm{Be} / 9 \mathrm{Be}$ ratios correlating with elevated $\mathrm{Ni} / \mathrm{Mn}$ ratios. Such patterns are best explained by protracted fluid-rock interactions leading to alteration of Mn-phases after crust formation. Isotopically light $\mathrm{Ni}$ is best explained by $\mathrm{Ni}$ isotope fractionation during adsorption rather than the contribution of external Ni sources (e.g. hydrothermal sources) having light $\mathrm{Ni}$ isotope compositions. The combination of our results with previously published data on $\mathrm{Fe}-\mathrm{Mn}$ crusts indicates that the average $\mathrm{Ni}$ isotope composition in deep waters has not changed through the Cenozoic $(\sim 70 \mathrm{Ma})$. We propose that $\mathrm{Ni}$ isotope variations in Fe-Mn crusts may not only record variations of $\mathrm{Ni}$ sources to the oceans, but also post-depositional processes depending on the growth history and geological settings of Fe-Mn crusts.
\end{abstract}

Keywords : Ferromanganese crusts ; Nickel isotopes ; Paleoceanography ; Pacific Ocean; Biogeochemical cycling 
27

28

\section{Introduction}

Fe-Mn crusts are seafloor metalliferous deposits forming through slow accumulation of seawater-derived Fe- and Mn-oxyhydroxide colloids on hard substrates such as volcanic seamounts that are kept sediment-free for millions of years (Craig et al., 1982; Halbach et al., 1983; Hein et al., 1988; Hein et al., 1992; Koschinsky and Halbach, 1995). Fe-Mn crusts are particularly abundant in the Northwest Pacific, e.g., the Pacific Prime Zone (Hein et al. (2013) and in the South Central Pacific (e.g., French Polynesia; Kosakevitch, 1987; Pichocki and Hoffert, 1987; Lesuave et al., 1989; Kosakevitch and Disnar, 1997) in connection with the formation and aging of Jurassic to Cretaceous volcanic seamounts (Halbach et al., 1983; Halbach and Puteanus, 1984; Halbach et al., 1984; Aplin and Cronan, 1985; De Carlo et al., 1987; Hein et al., 1988; Hein et al., 1992). A seawater origin for trace metals incorporated into Fe-Mn crusts has been well documented using isotopic and trace element geochemical signatures including rare earth elements (Bonatti and Joensuu, 1966; Bonatti et al., 1972; De Carlo et al., 1987; Nicholson et al., 1997; Hein et al., 2012; Bau et al., 2014). The importance of oceanographic parameters such as the depth of the oxygen-minimum-zone (OMZ), the calcite-compensation-depth (CCD) and phosphatization events that occurred during the Cenozoic have been well-recognized to influence Fe-Mn crusts geochemical composition (Hein et al., 1993). Hydrothermal input of metals have been also suggested in some cases (van de Flierdt et al., 2004; Chu et al., 2006; Horner et al., 2015) which is in line with the recognition that hydrothermal venting may impact regionally the inventory of metals, in particular Fe, in the deep ocean (Toner et al., 2009; Tagliabue et al., 2010; Conway and John, 2014; Fitzsimmons et al., 2014). In rare cases, cosmic spherules were also reported in South Pacific crusts (Kosakevitch, 1987; Halbach et al., 1989; Lesuave et al., 1989; Kosakevitch and 
51 Disnar, 1997) but it remains unclear whether such extra-terrestrial input could affect bulk Fe-

52 Mn crusts composition.

53 Radiogenic isotope geochemistry ( $\mathrm{Pb}, \mathrm{Sr}, \mathrm{Nd}, \mathrm{Os}, \mathrm{Hf})$ in $\mathrm{Fe}-\mathrm{Mn}$ crusts has been

extensively investigated in order to resolve fundamental paleoceanographic processes such as the evolution of oceanic circulation resulting from opening or closure of oceanic passages (e.g. closure of the Panama gateway, opening of the Drake passage), modifications in continental erosion fluxes after major climatic changes (von Blanckenburg et al., 1996b; Abouchami et al., 1997; Ling et al., 1997; O'Nions et al., 1998; Frank et al., 1999; Reynolds et al., 1999; Frank, 2002; Frank et al., 2002; van de Flierdt et al., 2003; Ling et al., 2005; Peate et al., 2009; Chen et al., 2013), and the impact of hydrothermal inputs (van de Flierdt et al., 2004). It should be noted that most of these studies were carried out on samples from the North Central Pacific Ocean. However other oceanic regions, including the South Pacific, have also important Fe-Mn crusts deposits (Hein et al., 2013) and they are poorly documented.

Stable isotope composition of metals (e.g., $\mathrm{Fe}, \mathrm{Zn}, \mathrm{Ni}, \mathrm{Cd}, \mathrm{Cu}, \mathrm{Tl}, \mathrm{Mo}$ ) in $\mathrm{Fe}-\mathrm{Mn}$ crusts and nodules, provide interesting proxies to unravel changes in the marine sources and biogeochemical cycles of metals through time (Zhu et al., 2000; Barling et al., 2001; Rehkämper et al., 2002; Siebert et al., 2003; Levasseur et al., 2004; Rehkämper et al., 2004; Anbar and Rouxel, 2007; Schmitt et al., 2009; Horner et al., 2010; Nielsen et al., 2011; Horner et al., 2015). However, the application of Ni stable isotopes as paleoceanographic proxies is not straightforward since at least three processes may affect the Ni isotope records preserved in Fe-Mn crusts: (1) changes in the relative fluxes of Ni sources and sinks in the ocean, (2) internal biogeochemical cycling of $\mathrm{Ni}$ and water mass mixing, and (3) fractionation processes during Ni incorporation at the Fe-Mn crust surface (Wasylenki et al., 2008; Wasylenki et al., 2011; Gueguen, 2013; Nielsen et al., 2013; Wasylenki et al., 2014a; 
76 Wasylenki et al., 2014b; Bryan et al., 2015) and Ni distribution among Mn-phases

77 (Koschinsky and Halbach, 1995; Koschinsky and Hein, 2003).

78 The isotope composition of $\mathrm{Ni}$ in marine systems has recently attracted significant 79 attention (Cameron and Vance, 2014) owing to its nutrient-type behavior (Sclater et al., 1976;

80 Cameron and Vance, 2014), and multiple sources in seawater (e.g., rivers, atmospheric

81 depositions, hydrothermal vents; Gall et al., 2013; Cameron and Vance, 2014; Little et al.,

82 2015). In a reconnaissance study, Gall et al. (2013) reported up to $1.6 \%$ variations in $\delta^{60 / 58} \mathrm{Ni}$

$83\left(\delta^{60 / 58} \mathrm{Ni}=\left({ }^{60} \mathrm{Ni} /{ }^{58} \mathrm{Ni}_{\text {sample }} /{ }^{60} \mathrm{Ni} /{ }^{58} \mathrm{Ni}_{\mathrm{NIST} 986}-1\right) \times 1000\right.$; see section 2.3$)$ along the growth

84 layers of Fe-Mn crusts from various ocean basins. The apparent absence of relationship

85 between $\mathrm{Ni}$ isotope variability and sample locations and depths implies that differences in

86 water masses, surface water productivity and bottom water oxygenation have no influence on

$87 \mathrm{Ni}$ isotope signatures preserved in Fe-Mn crusts. The Ni isotope composition of surface

88 scrapings of Fe-Mn crusts also shows significant variations in $\delta^{60 / 58} \mathrm{Ni}$ (from 0.9 to $2.5 \%$ )

89 with values being both heavier and lighter than the modern seawater value determined at 1.44

$90 \pm 0.15 \%$ (Cameron and Vance, 2014). While it has been argued that heavier Ni isotopes

91 values may be due to continental input and lighter Ni isotope values reflecting the extent of

92 hydrothermal input in deep waters (Gall et al., 2013), it remains unclear which processes are

93 controlling Ni isotope record in Fe-Mn crusts. Presumably, the importance of local or post-

94 depositional effects associated with $\mathrm{Ni}$ adsorption and precipitation in $\mathrm{Fe}-\mathrm{Mn}$ crusts should

95 also be considered as a potential cause of isotope fractionation as suggested by experimental

96 results of Ni sorption on Fe-oxyhydroxides (Sorensen et al., 2011; Gueguen, 2013; Wasylenki

97 et al., 2015) and Mn-oxyhydroxides (Gueguen, 2013; Wasylenki et al., 2014a) indicating

98 enrichment of the mineral phase in light $\mathrm{Ni}$ isotopes, keeping in mind that $\mathrm{Ni}$ is essentially

99 hosted in the Mn-phase. 
Here, we report Ni isotope composition of two pairs of Fe-Mn crusts collected on two

101

volcanic seamounts from the Northern Pacific Ocean (Apuupuu Seamount, Hawaii) and the Southern Pacific Ocean (near Rurutu Island, Austral archipelago of French Polynesia). This approach allows (a) a direct comparison of $\mathrm{Ni}$ isotope record in Fe-Mn crusts from the same seamount in order to address local effects, and (b) a comparison of geochemical composition of crusts between North and South Pacific in order to address the effect of more global geochemical processes. Through a high-resolution profile of major and trace element compositions, ${ }^{10} \mathrm{Be}$ dating and $\mathrm{Ni}$ isotope ratios, we tested the following hypotheses: (1) secular variations of $\mathrm{Ni}$ isotope in deep seawater should be reflected by co-variations in crusts recovered from the same locality, while differences should provide clues for post-depositional or local effects (2) differences between North and South Pacific crusts should provide information regarding the importance of oceanographic parameters (e.g., water masses) and the potential influence of hydrothermal sources.

\section{Materials and methods}

\subsection{Sample description and microsampling}

$$
\text { Two Fe-Mn crusts (samples J2-480 and J2-480-R14) were collected by the Remotely }
$$
Operated Vehicle (ROV) Jason2 (Woods Hole Oceanographic Institution) on Apuupuu Seamount $\left(155^{\circ} 25^{\prime} \mathrm{W}, 18^{\circ} 32 \mathrm{~N}\right)$, about $50 \mathrm{~km}$ south of Mauna Loa Volcano in Hawaii, at 2000 m water depth during the FeMO cruise (R/V Kilo Moana, University of Hawaii) in October 2009 (Figure 1). Although the samples from Apuupuu Seamount were sampled by using a ROV allowing a precise determination of sample location and depth, sample J2-480 could not be located since it originated from a set of samples that got mixed together in the 
125

126

127

128

129

130

131

132

133

134

135

136

137

138

139

140

141

142

143

144

145

146

147

148

ROV sampling basket. In addition, sample J2-480 was not collected attached to its substrate in contrast to sample J2-480-R14. The total thickness of both Apuupuu crusts was $\sim 60 \mathrm{~mm}$.

These samples will be referred in the paper as "North Pacific Fe-Mn crusts".

Two other Fe-Mn crusts (samples ZEP2-DR-05-04 and ZEP2-DR-06-03) were

collected by dredging in the South Pacific in the proximity of the Rurutu Island $\left(22^{\circ} \mathrm{S}\right.$,

$\left.150^{\circ} \mathrm{W}\right)$, Austral archipelago of French Polynesia, at $1826 \mathrm{~m}$ and $1530 \mathrm{~m}$ water depth during the ZEPOLYF2 cruise (R/V L'Atalante, Ifremer-Genavir) in July-August 1999. During this cruise, 24 dredges recovered volcanoclastic sediments, altered and fresh pillow basalts, hyaloclastites and Fe-Mn crusts (Bonneville et al., 2006; Adam and Bonneville, 2008) along the Cook-Austral volcanic chains in South Pacific. These samples will be referenced in this paper as "South Pacific Fe-Mn crusts”. Sample ZEP2-DR05-04 consisted of 25 mm thick FeMn crusts attached to a brecciated basalt substrate mixed with minor phosphorites and carbonates. Sample ZEP2-DR06-03 consisted of 90 mm thick Fe-Mn crusts lacking evidences for substrate attached at its bottom. In all cases, the smooth aspect of the top surface has been used to determine growth direction. Fe-Mn crust samples were further divided into two parts: the "top" corresponding to the surface of the crust in contact with seawater, the "middle" when no substrate was collected attached to the crust or the "bottom" when contact with the substrate is recovered. Based on mineral textures (see section 3) ZEP2-DR05-04 crust was further divided into subsections inner region "I" and outer region "O" (Figure 2).

The outermost layer of each crust (20 to $25 \mathrm{~mm}$ in thickness) was cut and embedded in epoxy resin. The surface was polished for petrographic examination and spatially resolved geochemical analyses (see below). Fe-Mn crusts were then subsampled with a microdrilling device (New Wave Micromill@). Layers perpendicular to the direction of growth were drilled to obtain a high-resolution microsampling every 1 to $2 \mathrm{~mm}$ of the crust growth layers (Figure 
149 2). Powders from the same layer were mixed and stored in small plastic centrifuge tubes to

150 obtain a total amount of powder between $\sim 30$ and $50 \mathrm{mg}$.

151

152

153

154

155

156

157

158

159

160

161

162

163

164

165

166

167

168

169

170

171

172

173

\subsection{Major and trace elements concentrations measurement}

Between 10 and $20 \mathrm{mg}$ of powdered samples were weighed in Teflon vials and digested in a mixture of $5 \mathrm{~mL}$ concentrated $\mathrm{HNO}_{3}$ and $5 \mathrm{~mL} 6 \mathrm{~mol} / \mathrm{L} \mathrm{HCl}$. After evaporation at $80^{\circ} \mathrm{C}$ on hot plates, the solid residue was dissolved with $5 \mathrm{~mL}$ of $6 \mathrm{~mol} / \mathrm{L} \mathrm{HCl}$ and then evaporated to dryness at $80^{\circ} \mathrm{C}$. This operation was reiterated once to ensure efficient dissolution of the samples. Solid residues were dissolved in $10 \mathrm{~mL} 6 \mathrm{~mol} / \mathrm{L} \mathrm{HCl}$ and $\mathrm{kept}$ as archive solutions. Reagents used for digestion and chemical procedures were prepared from sub-boiled distilled concentrated hydrochloric and nitric acids using a Cleanacids $®$ device (Analab, France).

Major and trace elements concentrations were measured by Quadrupole Inductively Coupled Plasma Mass Spectrometry (ICP-MS) (X-Series 2, Thermo-Finnigan) at the PôleSpectrométrie-Océan (IUEM-Ifremer, Brest, France) (Table 1) and precision was generally better than 5\%. Geological reference materials of manganese nodules Nod-A-1 and Nod-P-1 (US Geological Survey) were systematically analyzed along with samples and the measured concentrations fell within $10 \%$ uncertainty of the published concentration values (not shown).

\subsection{Nickel isotope analysis}

Nickel isotopes were measured at the Pôle-Spectrométrie-Océan (IUEM-Ifremer, Brest, France) by MC-ICP-MS (Neptune, Thermo Scientific). Nickel was separated from the geological matrix by ion-exchange chromatography columns involving two steps. First, the 
174 dissolved samples were processed through AG1-X8 resin in $6 \mathrm{~mol} / \mathrm{L} \mathrm{HCl}$ to separate $\mathrm{Ni}$ from

$175 \mathrm{Fe}, \mathrm{Zn}$ and most of $\mathrm{Co}$ and $\mathrm{Cu}$ that are retained on the column. Elution of $\mathrm{Ni}$ was made in 6

$176 \mathrm{~mol} / \mathrm{L} \mathrm{HCl}$. Afterwards, Ni was purified with Ni-spec resin (Eichrom) by complexation of Ni

177 with a DMG (Dimethylglyoxime) molecule allowing elution of the remaining matrix

178 elements. Eluted Ni fractions were evaporated and dissolved in $0.28 \mathrm{~mol} / \mathrm{L} \mathrm{HNO}_{3}$ for $\mathrm{MC}$ -

179 ICP-MS analyses. The experimental and analytical method is described in details in Gueguen

180 et al. (2013). Nickel isotope ratios were corrected from instrumental mass bias using the

181 double-spike method as described in Gueguen et al. (2013). The double-spike, a mixture of

${ }^{61} \mathrm{Ni}-{ }^{62} \mathrm{Ni}$ isotopes $\left({ }^{60} \mathrm{Ni} /{ }^{58} \mathrm{Ni}=0.732349 ;{ }^{61} \mathrm{Ni} /{ }^{58} \mathrm{Ni}=48.797310 ;{ }^{62} \mathrm{Ni} /{ }^{58} \mathrm{Ni}=44.346698\right)$, was

added to each sample with a $\mathrm{Ni}$ sample/spike ratio of 1 prior to chemical separation through

$\mathrm{Ni}$-spec resin. Application of a three-dimensional data reduction procedure was used to

determining the true isotope ratios of the samples (Siebert et al., 2001). Nickel isotope

compositions are reported in delta notation $\delta^{60 / 58} \mathrm{Ni}$ (per mil) relatively to the $\mathrm{Ni}$ isotopic

187 standard NIST SRM 986 (1):

188

189

190

191

192

193

194

195

196

197

$$
\delta^{60 / 58} \mathrm{Ni}=\left({ }^{60} \mathrm{Ni} /{ }^{58} \mathrm{Ni}_{\text {sample }} /{ }^{60} \mathrm{Ni} /{ }^{58} \mathrm{Ni}_{\mathrm{NIST} 986}-1\right) \times 1000
$$

Internal precision on $\mathrm{Ni}$ isotope delta values are determined as a two-standard error of the mean (2se) calculated with the 50 run cycles used for double-spike calculations (Gueguen et al., 2013) and is typically comprised between 0.03 and $0.04 \%$. External precision, determined by duplicate of digested and purified geological reference materials (Nod-A-1, Nod-P-1) and replicate of analysis of these materials on the mass spectrometer is determined at $0.04 \%$ (2sd; $n=7$; Table $1 \mathrm{~d})$ with $\delta^{60 / 58} \mathrm{Ni}$ values of $1.06 \%$ and $0.34 \%$ respectively. Error bars reported in the figures correspond to the external precision. 
199

200

201

202

203

204

205

206

207

208

209

210

211

212

213

214

215

216

217

218

219

220

221

222

223

\subsection{Beryllium isotope analysis}

Selected Fe-Mn crusts sub-samples were analyzed for ${ }^{10} \mathrm{Be} /{ }^{9} \mathrm{Be}$ ratio by Accelerator Mass Spectrometry (AMS ASTER) at CEREGE (Aix-en-Provence, France) using previously established methods (Bourles et al., 1989; Lebatard et al., 2008; Arnold et al., 2010). In short, collection of Be was made using a leaching method which consists in a chemical extraction of Be from its matrix using $0.04 \mathrm{M} \mathrm{NH}_{2} \mathrm{OH}-\mathrm{HCl}$ and $25 \%$ acetic acid. An aliquot of each sample was measured for ${ }^{9} \mathrm{Be}$ concentrations by graphite furnace atomic adsorption

spectrophotometry (GFAAS, Hitachi Z8200). The remaining of the sample was spiked with ${ }^{9} \mathrm{Be}$, and the total $\mathrm{Be}$ was purified using solvent extraction methods and then transformed to $\mathrm{BeO}$ for mass spectrometry analysis. ${ }^{10} \mathrm{Be}$ concentrations were calculated from the measured spiked ${ }^{10} \mathrm{Be} /{ }^{9} \mathrm{Be}$ ratios and the true ${ }^{10} \mathrm{Be} /{ }^{9} \mathrm{Be}$ ratio of the sample was calculated using ${ }^{9} \mathrm{Be}$ measured by GFAAS and ${ }^{10}$ Be measured by AMS. The precision for each sample analysis was determined on repeated measurements $(n=4)$ of the sample and the final uncertainty calculated on the ${ }^{10} \mathrm{Be} /{ }^{9} \mathrm{Be}$ ratio was generally better than $5 \%$.

\section{Results}

\subsection{Elemental geochemistry}

\subsubsection{North Pacific Fe-Mn crusts from Apuupuu Seamount}

Elemental concentrations and selected elemental ratios are reported in Table 1.

Average Mn concentrations are $\sim 14-15$ wt $\%$, whereas Fe contents are $\sim 10$ wt $\%$. Transition metal concentrations are in the range of $\sim 910$ to $4,700 \mu \mathrm{g} / \mathrm{g}$ for $\mathrm{Co}, \mathrm{Cu}$ and $\mathrm{Zn}$ concentrations yield average values of $\sim 1,000$ and $\sim 600 \mu \mathrm{g} / \mathrm{g}$ respectively, and the average Ni concentrations vary between $\sim 2,100$ and 3,000 $\mu \mathrm{g} / \mathrm{g}$ for J2-480 and J2-480-R14, respectively. Beryllium 
224

225

226

227

228

229

230

231

232

233

234

235

236

237

238

239

240

241

242

243 244 from 0.45 to $1.46(\mathrm{~g} / \mathrm{g})$ (Table 1$)$ which is typical of values already reported for other

245 hydrogenetic Fe-Mn crusts from the North and Central Pacific Ocean (Halbach et al., 1983; 246 De Carlo et al., 1987; Hein et al., 1988; Puteanus and Halbach, 1988; Koschinsky and 247 Halbach, 1995; Koschinsky et al., 1997; Frank et al., 1999; Hein et al., 2013; Hein and 248 Koschinsky, 2014). In general, compositional variations of transition metals are more

concentrations are homogenous in the range of 4.3 to $6.2 \mu \mathrm{g} / \mathrm{g}$ in $\mathrm{J} 2-480$ and 3.5 to $5.0 \mu \mathrm{g} / \mathrm{g}$ in J2-480-R14. Elements suggestive of authigenic enrichment of phosphatic minerals such as P yield average values of $\sim 25,000$ and $\sim 2,400 \mu \mathrm{g} / \mathrm{g}$ for $\mathrm{J} 2-480$ and J2-480-R14 respectively. In general, hydrogenetic Fe-Mn crusts display a perfect correlation between $\mathrm{P}$ and $\mathrm{Ca}$

concentrations, which is likely related to the fact that these two elements are essentially hosted in authigenic phosphatic phases. This is consistent with higher Ca concentrations of $54,000 \mu \mathrm{g} / \mathrm{g}$ obtained for $\mathrm{J} 2-480$ in comparison to Ca contents of $\sim 13,000 \mu \mathrm{g} / \mathrm{g}$ measured for J2-480-R14. Lithogenic elements such as Al and Ti have similar concentrations for the two North Pacific Fe-Mn crusts with values of $\sim 4,000 \mu \mathrm{g} / \mathrm{g}$ and $\sim 7,700 \mu \mathrm{g} / \mathrm{g}$ respectively. Although all samples fall in the hydrogenetic field in the ternary diagram (Figure 3) of Bonatti et al. (1972), it should be noted that the bottom of crust J2-480 tends towards the hydrothermal field due to higher Fe concentrations and lower $\mathrm{Mn}, \mathrm{Ni}, \mathrm{Cu}$ and $\mathrm{Co}$ concentrations. As reported in other studies, the concentration patterns of, $\mathrm{Ni}, \mathrm{Co}$, and $\mathrm{Cu}$ tend to covary with Mn concentrations (Koschinsky and Halbach, 1995; Koschinsky and Hein, 2003) suggesting that the Mn-phase controls the distribution and enrichment of these metals in the crust. Therefore, we also normalized transition metal concentrations to $\mathrm{Mn}$ in order to avoid possible dilution effects due to the presence of other phases (e.g., phosphates, silicates, Fe-oxyhydroxides). When normalized to Mn concentrations, contents of metals such as $\mathrm{Cu}$, $\mathrm{Ni}, \mathrm{Co}$, and $\mathrm{Zn}$ to a lesser extent show an increase below $\sim 15 \mathrm{~mm}$ in crust $\mathrm{J} 2-480$ and below $\sim 9 \mathrm{~mm}$ in crust J2-480-R14 (Figure 4). Fe/Mn ratios determined for each growth layer range 
249

250

251

252

253

254

255

256

257

258

259

260

261

262

263

264

265

266

267

268

269

270

271

272

273

pronounced in J2-480 than in J2-480-R14 (Figure 4). Fe/Mn ratios increase in J2-480 at 15 mm depth from $\sim 0.60$ to $\sim 1.40$ whereas it remains stable in $\mathrm{J} 2-480-\mathrm{R} 14$. Al/Fe ratios, which are used as an estimate of the lithogenic contributions, vary between 0.03 and 0.06 in crust J2480-R14. These variations, however, are not specifically correlated with other metals concentrations. By contrast, A1/Fe sharply increases in $\mathrm{J} 2-480$ crust from $~ 15 \mathrm{~mm}$ depth towards the bottom from 0.03 to 0.15 which also corresponds to the increase in other transition metals such as $\mathrm{Cu}, \mathrm{Ni}$ and $\mathrm{Co}$ (Figures 4 and 6).

\subsubsection{South Pacific Fe-Mn crusts from French Polynesia}

South Pacific Fe-Mn crusts have lower Mn concentrations (average Mn 9-10 wt\%) than North Pacific Fe-Mn crusts and they also have lower Fe contents (average Fe 8 wt \%) (Table 1). Average Co concentrations range between $\sim 4,800$ and 5,400 $\mu \mathrm{g} / \mathrm{g}$, while other transition metals like $\mathrm{Cu}$ and $\mathrm{Zn}$ show average concentrations of $\sim 500$ and $\sim 300 \mu \mathrm{g} / \mathrm{g}$ respectively. Ni concentrations are on average comprised between $\sim 1,200$ and 2,000 $\mu \mathrm{g} / \mathrm{g}$. Beryllium concentrations are in general lower than in North Pacific Fe-Mn crusts and vary between 1.4 to $4.1 \mu \mathrm{g} / \mathrm{g}$ in ZEP2-DR05-04 and between 2.0 and 3.1 in ZEP2-DR-06-03. The two Fe-Mn crusts display distinct average Ca concentrations, i.e. 14,000 $\mu \mathrm{g} / \mathrm{g}$ in ZEP2DR05-04 and 44,000 $\mu \mathrm{g} / \mathrm{g}$ in ZEP2-DR06-03. Calcium concentrations are in agreement with distinct $\mathrm{P}$ concentrations observed between the two Fe-Mn crusts, where $\mathrm{P}$ concentrations in ZEP2-DR05-04 are $\sim 3,600 \mu \mathrm{g} / \mathrm{g}$ on average and $\sim 7,700 \mu \mathrm{g} / \mathrm{g}$ in ZEP2-DR06-03. The latter displays a 10-fold increase in $\mathrm{Ca}$ and $\mathrm{P}$ concentrations from the surface of the crust to the base of the crust, i.e., from $\sim 12,000 \mu \mathrm{g} / \mathrm{g}$ to $\sim 120,000 \mu \mathrm{g} / \mathrm{g}$ for $\mathrm{Ca}$ and from $\sim 2,900 \mu \mathrm{g} / \mathrm{g}$ to $\sim 31,000 \mu \mathrm{g} / \mathrm{g}$ for $\mathrm{P}$, with a steep increase from $\sim 12 \mathrm{~mm}$ and $\sim 23 \mathrm{~mm}$ depth in the crust. This suggests significant phosphatization in ZEP2-DR06-03. Finally, we found similar ranges of 
$274 \mathrm{Al}$ and Ti concentrations than for North Pacific Fe-Mn crusts of $\sim 4,000 \mu \mathrm{g} / \mathrm{g}$ and $\sim 2,700 \mu \mathrm{g} / \mathrm{g}$ 275 respectively.

276 The range of Fe/Mn ratios from 0.53 and 1.31 in the South Pacific Fe-Mn crusts are 277 similar to the ratios measured in North Pacific Fe-Mn crusts and they are also in the range of 278 Fe/Mn ratios reported for other South Pacific Fe-Mn crusts (Frank et al., 1999; Hein et al., 279 2013). All subsamples of the two Fe-Mn crust profiles fall in the hydrogenetic field (Figure 3) 280 of the Bonatti et al. (1972) diagram. However, differences between North and South Pacific 281 Fe-Mn crusts are observed in terms of enrichment factors between each crust such that Co 282 enrichment, i.e., $\mathrm{Co} / \mathrm{Mn}$ ratios, are higher $(\mathrm{Co} / \mathrm{Mn}>0.04)$ in South Pacific Fe-Mn crusts than 283 for in North Pacific Fe-Mn crusts (Co/Mn 0.02; Figure 5 and Table 1). In addition, we 284 distinguished two distinct regions, "I" and "O", in ZEP2-DR05-04 crust since they display 285 significant geochemical differences (Figure 4). Region “O” is between $0.5 \mathrm{~mm}$ (top) to 16.5 $286 \mathrm{~mm}$ depth in the crust, and region "I" includes layers from $17.5 \mathrm{~mm}$ to $22 \mathrm{~mm}$ depth (i.e., over 287 a thickness of $\sim 4 \mathrm{~mm}$ at the bottom of the crust). The region "I" shows a two-fold difference 288 in $\mathrm{Ni}$ and $\mathrm{Cu}$ concentrations compared to the region "O" (Figure 4). Other layers in the crust 289 show remarkably similar geochemical patterns, in particular with respect to $\mathrm{Cu} / \mathrm{Mn}, \mathrm{Co} / \mathrm{Mn}$, $290 \mathrm{Ni} / \mathrm{Mn}$ and $\mathrm{Fe} / \mathrm{Mn}$ ratios. Ni/Mn ratios vary around an average value of 0.15 , while $\mathrm{Zn} / \mathrm{Mn}$ 291 and $\mathrm{Cu} / \mathrm{Mn}$ ratios are slightly decreasing from bottom to top of the crusts (i.e., from $\sim 0.002$ to 2920.040 for $\mathrm{Zn} / \mathrm{Mn}$ and from $\sim 0.002$ to 0.060 for $\mathrm{Cu} / \mathrm{Mn}$ ). Co/Mn ratios decrease from about 2930.075 to 0.04 in the first $5-10 \mathrm{~mm}$ of the crust, and remain relatively constant at $\sim 0.05$ from 29410 to $25 \mathrm{~mm}$. This possibly indicates a decrease in growth rates of the crusts. Aluminum 295 enrichment relative to Fe is different between the two crusts, ZEP2-DR06-03 crust displays 296 constant $\mathrm{Al} / \mathrm{Fe}$ ratio from $10 \mathrm{~mm}$ depth towards the bottom of the crust with values $\sim 0.050$,

297 while it decreases from $10 \mathrm{~mm}$ depth to the top of the crust to values up to 0.026 . These 298 values are well below the average Al/Fe ratio of the Upper Continental Crust of 3.06 
299 (Rudnick and Gao, 2014) consistent with a limited detrital component in Fe-Mn crusts. ZEP2-

300 DR05-04 crust shows constant Al/Fe ratios centered $\sim 0.040$, but significantly increase up to

3010.112 from $17.5 \mathrm{~mm}$ depth towards the bottom of the crust. The shift is concomitant to the 302 increase in $\mathrm{Ni} / \mathrm{Mn}, \mathrm{Cu} / \mathrm{Mn}$ and $\mathrm{Zn} / \mathrm{Mn}$ ratios.

303

304

3.2. Fe-Mn crust dating and calculation of growth rates using Be isotope ratios

305

306

307

308

309

310

311

312

313

314

315

316

317

318

319

320

321

322

323

A common method for dating Fe-Mn crusts has involved the measurement of the cosmogenic isotope ${ }^{10} \mathrm{Be}$ (Tanaka and Inoue, 1979; Segl et al., 1984; Bourles et al., 1989;

Morris, 1991; Ling et al., 1997; Frank et al., 1999; Frank et al., 2002; Ling et al., 2005;

Amend et al., 2011). Although the Co-dating method (i.e., Co enrichment in the crust) has been used in the past (e.g., Halbach et al., 1983), it could yield inaccurate ages in the case of variable Co fluxes to the oceans (Kyte et al., 1993). The Be dating method is based on the assumption that ${ }^{10} \mathrm{Be}$ is supplied at a constant rate to the oceans, so that ${ }^{10} \mathrm{Be} /{ }^{9} \mathrm{Be}$ ratios should be uniform in the surface layer of Fe-Mn crusts (Ku et al., 1990; von Blanckenburg et al., 1996a; Willenbring and von Blanckenburg, 2010a). The advantage of this method is the determination of an absolute age of Fe-Mn crust, which is not affected by possible hiatuses during crust growth. Since ${ }^{10} \mathrm{Be}$ has a short half-life of $1.39 \mathrm{Ma}$ (Willenbring and von Blanckenburg, 2010a), this method can only be used for dating Fe-Mn crusts up to 20 Ma.

Hence, we measured ${ }^{10} \mathrm{Be} /{ }^{9} \mathrm{Be}$ ratios only for the top $2.5 \mathrm{~cm}$ of each crust. We calculated absolute ages of subsamples using an initial ${ }^{10} \mathrm{Be} /{ }^{9} \mathrm{Be}$ ratio of $1.1 \times 10^{-7}$ (von Blanckenburg et al., 1996a) and a $\lambda$ value of $0.498667036 \mathrm{myr}^{-1}$ for ${ }^{10} \mathrm{Be}$ (Table 2).

${ }^{10} \mathrm{Be} /{ }^{9} \mathrm{Be}$ ratios in $\mathrm{J} 2-480$ range from $3.14 \times 10^{-9}$ at the top of the crust to $2.71 \times 10^{-10}$ towards the bottom of the crust (Table 2 and Figure 5). A larger range is observed for J2-480R14 from $1.75 \times 10^{-8}$ at the top of the crust to $2.31 \times 10^{-11}$ towards the bottom. Results for J2- 
324 480-R14 crust show near linear decrease of $\operatorname{Ln}\left({ }^{10} \mathrm{Be} /{ }^{9} \mathrm{Be}\right)$ with crust depth suggesting constant 325 growth rate, at least for the top $18 \mathrm{~mm}$ of the crust (Figure 5) which was estimated at $1.1 \pm 0.5$ $326 \mathrm{~mm} / \mathrm{Ma}$. Precise dating of sample J2-480 is impaired by the limited subsampling intervals 327 (only 3 data points) but an average growth rate of $1.6 \mathrm{~mm} / \mathrm{Ma}$ was determined. From the top 328 to bottom layer, J2-480 and J2-480-R14 crust sections span an age from 7.1 to $12.0 \mathrm{Ma}$ and 3293.7 to 17.0 Ma respectively. The results suggest that both Fe-Mn crusts from Apuupuu 330 Seamount have similar average growth rates, consistent with similar Co/Mn ratios of $0.021 \pm$ $331 \quad 0.01$ and $0.031 \pm 0.01$ respectively. A striking result of ${ }^{10} \mathrm{Be}$ dating is that the uppermost layer 332 of the crusts does not show "zero" ages as expected. Possible explanations are either that Fe333 Mn crusts J2-480 and J2-480-R14 stopped growing some millions years ago (i.e., presence of 334 hiatuses), or that the top part of the crusts was broken and was not recovered during the 335 sampling process. The lack of significant Co enrichment in the uppermost layers compared to 336 other section of the crusts argues against an abrupt decrease in growth rates. Using the 337 average growth rates obtained for each crust, the estimated thickness of the uppermost crust 338 layers that appear missing is about $11 \mathrm{~mm}$ for J2-480 and $4 \mathrm{~mm}$ for J2-480-R14. Hence, it is 339 possible that the first centimeters of the crust layers were lost during sampling, probably due 340 to the difficulty to recover these samples from smooth surface of bare rocks using the 341 articulated arm of the ROV (Figure 2). ${ }^{10} \mathrm{Be} /{ }^{9} \mathrm{Be}$ ratios from $6.91 \times 10^{-8}$ to $3.51 \times 10^{-9}$ are observed in ZEP2-DR06-03 crust with

343 decreasing values from top to bottom of the crust. ZEP2-DR05-04 crust shows a different 344 pattern where Be isotopes do not follow the expected trend if radioactive decay is the only 345 controlling factor. In this sample, ${ }^{10} \mathrm{Be} /{ }^{9} \mathrm{Be}$ ratios range from $1.40 \times 10^{-7}$ at about $17.5 \mathrm{~mm}$ from 346 top, $1.02 \times 10^{-8}$ at $\sim 0.5 \mathrm{~mm}$ and $6.50 \times 10^{-9}$ at $12.5 \mathrm{~mm}$ (Table 2 and Figure 5). Hence, ZEP2-

347 DR05-04 crust displays anomalously high ${ }^{10} \mathrm{Be} /{ }^{9} \mathrm{Be}$ ratios in the bottom, i.e., older part of the 348 crust (Figure 5). In particular, ${ }^{10} \mathrm{Be} /{ }^{9} \mathrm{Be}$ ration of $1.4 .10^{-7}$ measured at $17.5 \mathrm{~mm}$ is similar, 
349 albeit slightly higher, than the present-day ${ }^{10} \mathrm{Be} /{ }^{9} \mathrm{Be}$ ratio in seawater. Potential reasons for the 350 aberrant youth of the crust are discussed in more details below. We cautiously avoided using 351 the ${ }^{10} \mathrm{Be} /{ }^{9} \mathrm{Be}$ data to provide age estimates for ZEP2-DR05-04.

352 Layers of ZEP2-DR-06-03 can be divided into two parts in terms of growth rates. The upper half crust from depth to 0.5 to $\sim 13 \mathrm{~mm}$ depth is characterized by an average growth rate 354 estimated at $1.7 \pm 0.6 \mathrm{~mm} / \mathrm{Ma}$, while the second half part of the crust corresponding to depths between $\sim 13 \mathrm{~mm}$ and $23.5 \mathrm{~mm}$ has an average higher growth rate of $3.2 \pm 0.6 \mathrm{~mm} / \mathrm{Ma}$. The variations in growth rates is consistent with the increase in Co/Mn ratios from $\sim 13 \mathrm{~mm}$ to 0.5 mm depth in the crust (Figure 5) suggesting enrichment in Co concentrations due to lower 358 growth rates. These growth rates are generally in the range reported in the literature for 359 hydrogenetic Fe-Mn deposits (Frank et al., 1999; Frank, 2002). The time periods spanned by 360 ZEP2-DR06-03 subsamples is between 0.9 and 6.9 Ma. and ZEP2-DR06-03 (Figure 5), including the "kink" at 5 mm depth, we consider that both crusts have on average similar growth rates.

364

\subsection{Ni isotope ratios} uniform in the range of 1.64 to $1.72 \%$ for crust $\mathrm{J} 2-480$ with the exception of the most basal 369 point at $19 \mathrm{~mm}$ depth yielding a $\delta^{60 / 58} \mathrm{Ni}$ value of $+1.41 \%$. Sample J2-480-R14 displays 370 variations from 1.70 to $1.86 \%$ with the exception of the top of J2-480-R14 at $0.2 \mathrm{~mm}$ depth, 371 which has a heavier $\delta^{60 / 58} \mathrm{Ni}$ of $1.94 \%$ (Figure 6 and Table 2). Average values are $1.65 \pm 0.19$ 372 $\% \circ(2 \mathrm{sd})$ and $1.79 \pm 0.13 \%$ (2sd) for J2-480 and J2-480-R14 respectively, and although the 373 observed variations exceed the reproducibility of the measurements (i.e., $\pm 0,04 \%$ ) the range 
374 falls within the range of previously published data (Gall et al., 2013). Nickel isotope

375 compositions of South Pacific Fe-Mn crusts subsamples vary from 1.75 to $1.95 \%$ in ZEP2-

376 DR06-03 crust with an average value of $1.87 \pm 0.10 \%$ (2sd, n=14). In ZEP2-DR05-04 crust,

377 the "I" region of the crust show a significant variability in $\delta^{60 / 58} \mathrm{Ni}$ values from 0.25 to $1.08 \%$

378 with lowest values at the bottom of the crust in contact with the substrate. In contrast, $\delta^{60 / 58} \mathrm{Ni}$

379 values in the "O" region are comprised between 1.54 to $1.86 \%$ with an average value of 1.72

$380 \pm 0.18 \%$ (Table 2 and Figure 6). Light $\mathrm{Ni}$ isotope compositions correlates with low $\mathrm{Mn} / \mathrm{Ni}$

381 ratios $\left(R^{2}=0.99\right.$ for the last five samples at the bottom of the crust; Figure 7D). With the

382 exception of the inner region "I" of ZEP2-DR05-04 crust, both range of values in the South

383 Pacific Fe-Mn crusts are similar to North Pacific Fe-Mn crusts.

384

385 4. Discussion

386

4.1. Mechanisms of Ni incorporation into Fe-Mn crusts and Ni isotope variability of Fe-Mn

388

389

390

391

392

393

394

395

396

397

crusts surfaces

Nickel isotope composition of surface layers of hydrogenetic Fe-Mn crusts scrapings

from various localities previously reported by Gall et al. (2013) shows a range from 0.9 to 2.5

$\%$ with an average value of $1.62 \pm 0.78 \%$, which indicates both lighter and heavier values

than the average Ni isotope composition of seawater of $1.44 \pm 0.15 \%$ (Cameron and Vance, 2014). However, it is important to recall that even surface scrapings of Fe-Mn crusts do not exactly represent an instantaneous picture of ambient seawater. Considering average growth rates between 1 to $5 \mathrm{~mm} / \mathrm{Ma}$ typical for Fe-Mn crusts, precise sampling (i.e., scraping) of the first 0.1 to $0.5 \mathrm{~mm}$ of Fe-Mn crust yield ages ranging from $0.5 \mathrm{Ma}$ to not less than $20 \mathrm{ka}$. 
398

399

400

401

402

403

404

405

406

407

408

409

410

411

412

413

414

415

416

417

418

419

420

421

422

Hence, the time resolution is significantly longer than the estimated residence time of $\mathrm{Ni}$ in the ocean and it is possible that $\mathrm{Ni}$ isotope composition in seawater changed during that time.

Gall et al. (2013) observed that the surface scrapings of Fe-Mn crusts formed close to continental margins yielded heavier $\delta^{60 / 58} \mathrm{Ni}$ values up to $2.5 \%$ which could be attributed to a higher contribution of input materials from continental weathering (e.g., rivers and groundwaters). The authors also discussed the effect of deep ocean water redox state and showed that no correlation could be established between oxygen saturation state and $\mathrm{Ni}$ isotope variations. In this study, we obtained a single $\delta^{60 / 58} \mathrm{Ni}$ value of $1.88 \pm 0.04 \%$ o for crust layers younger than $0.9 \mathrm{Ma}$ (i.e., sample ZEP2-DR06-03-L1). This value is remarkably similar to the average value of the crust for the last $7 \mathrm{Ma}$ (Tables 1 and 2), suggesting that seawater $\mathrm{Ni}$ isotope values as recorded in Fe-Mn crusts remained relatively constant. By comparison, Gall et al. (2013) obtained lighter $\delta^{60 / 58} \mathrm{Ni}$ value at $1.04 \pm 0.25 \%$ (2sd) for the surface scraping of a Fe-Mn crust recovered about $400 \mathrm{~km}$ westward (Fe-Mn crust SO-36, $22^{\circ} 21^{\prime} \mathrm{S}, 150^{\circ} 17^{\prime} \mathrm{W}$ ) of the studied ZEP2-DR06-03 Fe-Mn crust. Both values are different from modern seawater estimated at $1.44 \pm 0.15 \%$ (Cameron and Vance, 2014).

Recent experimental work has shown relatively large Ni isotope fractionation during Ni sorption to Fe-oxyhydroxides (Gueguen et al., 2011; Sorensen et al., 2011; Gueguen, 2013; Wasylenki et al., 2015) and Mn-oxyhydroxides (Gueguen, 2013; Wasylenki et al., 2014a) with preferential uptake of isotopically light $\mathrm{Ni}$ on the mineral surface. Results on natural samples show that to a first approximation the enrichment in the heavy Ni isotopes in the surface layer of Fe-Mn crusts relative to seawater $(1.88 \pm 0.10 \%$ vs $1.44 \pm 0.15 \%$ o $)$ is at odds with experimental studies showing preferential enrichment in light $\mathrm{Ni}$ isotopes on Mn-oxides surface (e.g., birnessite) by up to $-2.5 \%$ (Gueguen, 2013; Wasylenki et al., 2014a).

Enrichment in heavy Ni isotopes for surface scrapings ( $\delta^{60 / 58} \mathrm{Ni}$ value up to $2.00 \pm 0.05 \%$ ) has been also reported elsewhere in the South or North Central Pacific (Gall et al., 2013). This 
423 suggests either that another mechanism rather than adsorption reactions is responsible for

424 heavy isotope fractionation during Ni uptake in Fe-Mn crusts or that seawater changed rapidly

425 within the last $1 \mathrm{Ma}$. We discuss below possible mechanisms explaining both heavier and 426 lighter $\mathrm{Ni}$ isotope composition in Fe-Mn crusts relative to seawater.

427 Ferromanganese crusts are formed through the slow precipitation of Fe-Mn colloids,

428 initially formed in seawater, on a hard substrate devoid of sediments (Koschinsky and

429 Halbach, 1995). Metal cations, such as Ni are readily coprecipitated with Fe-Mn colloids and

430 can undergo further precipitation through slow uptake (i.e., adsorption) onto Fe-Mn crust

431 surface. Hence, even if the removal of Ni onto Fe-Mn colloids in the water column is

432 relatively rapid, which should result in significant $\mathrm{Ni}$ isotope fractionation, most of $\mathrm{Ni}$

433 adsorption occurs directly on the crust surface. EXAFS results on experimental Ni adsorption

434 on birnessite at neutral $\mathrm{pH}$ indicate that adsorbed $\mathrm{Ni}$ is structurally incorporated within the

435 mineral with time, e.g., 30\% of Ni is incorporated within 408 hours (Peacock, 2009). Thus, it

436 is possible that adsorbed $\mathrm{Ni}$ on Fe-Mn crust surface is continuously incorporated in the

437 mineral structure as a result of long exposure of the crust surface to seawater. This process

438 would allow isotopic exchange of $\mathrm{Ni}$ with seawater and any potential isotope fractionation

439 that would have initially occurred during adsorption reactions would not necessarily be

440 recorded in the final product of the reaction. In support of this hypothesis, the experimental

441 study of $\mathrm{Cd}$ isotope fractionation during adsorption of $\mathrm{Cd}$ on birnessite in high ionic strength

442 solution (i.e., artificial seawater) indicated that the isotope fractionation factor between

443 dissolved $\mathrm{Cd}$ and adsorbed $\mathrm{Cd}$ decreases with time, from $0.4 \%$ at the beginning of

444 experiment to $0.1 \%$ after 912 hours (Wasylenki et al., 2014b). The final Cd isotope

445 fractionation factor $\sim 0.1 \%$ was similar to the isotope fractionation of $\mathrm{Cd}$ observed during

446 experiments in low ionic strength solution and that measured between seawater and Fe-Mn

447 crusts (Schmitt et al., 2009; Horner et al., 2010). The experimental data suggest, therefore, a 
448 reversible mechanism during exchange of dissolved $\mathrm{Cd}$ and adsorbed $\mathrm{Cd}$ in high ionic

449 strength conditions. It is possible that a similar mechanism explains the range of $\mathrm{Ni}$ isotope 450 composition in Fe-Mn crusts, that is, the structural incorporation of $\mathrm{Ni}$ within the crust with 451 time favors the heavy $\mathrm{Ni}$ isotopes while initial adsorption of $\mathrm{Ni}$ onto Fe-Mn minerals favors 452 the light $\mathrm{Ni}$ isotopes.

It has been shown that $\mathrm{Ni}$ speciation in seawater is dominated by aqueous $\mathrm{Ni}^{2+}$ and $\mathrm{Ni}-$

454 chloro complexes (Bruland, 1980; Bruland, 1983; Bruland et al., 1994; Fujii et al., 2011), as

455 well as organically-bound species (Van Den Berg and Nimmo, 1987; Nimmo et al., 1989;

456 Turner et al., 1998). In addition, experimental and theoretical results indicate that Ni isotopes

457 are prone to large fractionation up to $\sim 2.5 \%$ o between isotopically heavy inorganic and

458 isotopically light organic Ni species in seawater (Fujii et al., 2011), which demonstrates that

$459 \mathrm{Ni}$ speciation in the water column may also affect $\mathrm{Ni}$ isotope composition of Fe-Mn crusts. In

460 the case of the preferential adsorption of aqueous $\mathrm{Ni}^{2+}$ species on Mn-oxides colloids relative

461 to isotopically light organic species (e.g., Nickel carboxylate complexes; Fujii et al., 2011),

462 the expected enrichment in light $\mathrm{Ni}$ isotopes during adsorption will be muted by the inverse

463 fractionation between inorganic and organic Ni species in solution. In similar manner, Little et

464 al. (2014b) interpreted heavier Zn isotope compositions of Fe-Mn crusts relative to seawater

465 as the result of fractionation between free aqueous $\mathrm{Zn}^{2+}$ (preferentially adsorbed on Fe-Mn

466 crusts) and $\mathrm{Zn}$ chloro-complexes, the latter being predicted to favor light $\mathrm{Zn}$ isotopes. Because

467 free $\mathrm{Ni}^{2+}$ and $\mathrm{Ni}$-chloro complexes are also the predominant species occurring in seawater

468 (Fujii et al., 2011), with Ni-chloro complexes being enriched in light Ni isotopes compared to

469 aqueous $\mathrm{Ni}^{2+}$ (Fujii et al., 2011), similar mechanisms could affect both $\mathrm{Ni}$ and $\mathrm{Zn}$ isotopes in

470 Fe-Mn crusts. However, although Ni speciation certainly plays an important role in the

471 fractionation of $\mathrm{Ni}$ isotopes between $\mathrm{Fe}-\mathrm{Mn}$ crusts and seawater, it is unlikely that the relative

472 abundance of free $\mathrm{Ni}^{2+}$ and $\mathrm{Ni}$-chloro complexes is variable in seawater. Hence, Ni speciation 
473 in seawater is unlikely to explain the range of $\mathrm{Ni}$ isotopes in Fe-Mn crusts within oceanic

474 basins. Processes involving the pathways of $\mathrm{Ni}$ incorporation in Fe-Mn crusts therefore

475 provide the most plausible mechanisms, together with post-depositional effects as discussed

476 in the following section 4.2.

477

478

479

480

481

482

483

484

485

486

487

488

489

490

491

492

493

494

495

496

497

4.2. Evidence for diagenetic alteration and post-depositional effects in Fe-Mn crusts and the response of $\mathrm{Ni}$ isotopes to late-stage alteration

The high ${ }^{10} \mathrm{Be} /{ }^{9} \mathrm{Be}$ ratios in the region "I" of ZEP2-DR05-04 crust (Table 2 and Figures 5) is at odds with the general assumption that Fe-Mn crusts are composed of Fe-Mn oxides layers that accumulated successively through time onto a hard substrate, implying that ${ }^{10} \mathrm{Be} /{ }^{9} \mathrm{Be}$ ratios in the crust profile should decrease from top to bottom. The inner region "I" of this crust also corresponds to the region where important geochemical variability is observed, in particular with respect to $\mathrm{Mn}, \mathrm{Fe}, \mathrm{Ni}$, and $\mathrm{Cu}$ concentrations. There is an increase in $\mathrm{Cu} / \mathrm{Mn}, \mathrm{Ni} / \mathrm{Mn}, \mathrm{Zn} / \mathrm{Mn}$ and $\mathrm{Al} / \mathrm{Fe}$ ratios at the bottom of ZEP2-DR05-04 while Co/Mn ratios remain similar to the other crust ZEP2-DR06-03 recovered from the same area. In the outer region "O" of the crust, $\mathrm{Cu} / \mathrm{Mn}, \mathrm{Fe} / \mathrm{Mn}$ and $\mathrm{Zn} / \mathrm{Mn}$ are remarkably similar between both crusts. This suggests that growth rates or water mass parameters are not the major controls on the enrichment in Ni and other transition metals in crust ZEP2-DR05-04. Below, we consider three possible explanations that may account for the anomalously high ${ }^{10} \mathrm{Be} /{ }^{9} \mathrm{Be}$ ratios and associated geochemical variations: (1) unusually high initial ${ }^{10} \mathrm{Be} /{ }^{9} \mathrm{Be}$ ratios; (2) diffusion processes; (3) phosphatization effects; and (4) protracted seawater circulation throughout the base of the crust in contact with the substrate.

Hypothesis (1): most of the flux of cosmogenic ${ }^{10} \mathrm{Be}$ to the ocean has an atmospheric origin and is directly related to the flux of the incoming cosmic ray particles (Willenbring and 
498

499

500

501

502

503

504

505

506

507

508

509

510

511

512

513

514

515

516

517

518 skewed the age model based on ${ }^{10} \mathrm{Be} /{ }^{9} \mathrm{Be}$ isotope ratios.

519

520

521

522 ratios in our sample. sked the age model based on ${ }^{10} \mathrm{Be} /{ }^{9} \mathrm{Be}$ isotope ratios.

von Blanckenburg (2010b, 2010a); Steinhilber et al. (2012) and references therein). Although

variations in geomagnetic field strength and changes in solar modulation produce fluctuations in ${ }^{10} \mathrm{Be}$ flux, it remained roughly constant over the last $12 \mathrm{Ma}$ (Willenbring and von

Blanckenburg, 2010b). ${ }^{9} \mathrm{Be}$ fluxes to the ocean, mainly derived from fluvial inputs also remained constant, precluding a change of initial ${ }^{10} \mathrm{Be} /{ }^{9} \mathrm{Be}$ ratios during the formation of the crusts. In addition, ${ }^{9} \mathrm{Be}$ concentrations are relatively constant through the Fe-Mn crust layers (Table 2), suggesting that unusual high ${ }^{10} \mathrm{Be} /{ }^{9} \mathrm{Be}$ ratios are not the results of ${ }^{9} \mathrm{Be}$ depletion. Although cosmic spherules have been already reported in Fe-Mn crusts (e.g., Kosakevitch, 1987; Halbach et al., 1989), high initial ${ }^{10} \mathrm{Be} /{ }^{9} \mathrm{Be}$ ratios are unlikely to originate from the presence of meteoritic particles with high ${ }^{10} \mathrm{Be}$ content since cosmic particles yield ${ }^{10} \mathrm{Be}$ below $0.17 \mathrm{pg} / \mathrm{g}$ (Nishiizumi et al., 1991). Stuart and Lee (2012) detected the presence of micrometeorites using He isotopic composition of Fe-Mn crusts, however their Fe-Mn crust was dated using cosmogenic ${ }^{10} \mathrm{Be}$ isotope implying that extraterrestrial inputs have not modified the ${ }^{10} \mathrm{Be} /{ }^{9} \mathrm{Be}$ ratios of $\mathrm{Fe}-\mathrm{Mn}$ crust. Hence, the presence of extraterrestrial material is probably not the cause of elevated ${ }^{10} \mathrm{Be} /{ }^{9} \mathrm{Be}$ isotope ratios, and probably also elevated Ni/Mn

Hypothesis (2) can also be disregarded since it was demonstrated that on the timescale considered for dating Fe-Mn crusts diffusion of Be is very limited (Henderson and Burton, 1999). If diffusion processes affect Be in the crust, it could modify the isotopic pattern showing decreasing values from top (young crust) to the bottom (old crust) and

Hypothesis (3): the presence of accessory phases such as fluorapatite and calcite generally indicates alteration processes in the Fe-Mn crust with possible remobilization of transition metals in the crust. This effect, known as phosphatization, has been described in some Pacific Fe-Mn crusts (Halbach and Puteanus, 1984; Hein et al., 1993). Phosphorus and 
523 calcium in Fe-Mn crusts are essentially hosted in accessory fluorapatite and calcite phases,

524 with minor contribution from detrital materials and their concentrations vary in our Fe-Mn

525 crusts, in particular crust ZEP2-DR06-03 (Table 1). However, variations in P concentrations

526 are not correlated with any variations in transition metal concentrations nor with isotopic

527 variations (Figure 7), suggesting that phosphatization effects can be discounted for explaining

528 the compositional variability in our Fe-Mn crusts. More specifically, the bottom of crust

529 ZEP2-DR05-04 (with anomalous ${ }^{10} \mathrm{Be} /{ }^{9} \mathrm{Be}$ ratios) does not show any specific trend in $\mathrm{P}$

530 concentrations (Figure 7) indicating that the crust did not undergo major phosphatization,

531 which is thus unlikely to be the cause for the variations observed in other geochemical

532 proxies. Finally, large $\mathrm{P} / \mathrm{Ni}$ ratios also do not correlate with $\delta^{60 / 58} \mathrm{Ni}$ values (Figure 7).

533 Finally, hypothesis (4) and the effect of post-depositional fluid circulation through the

534 crust is likely the most plausible explanation for our observations. Several lines of evidence

535 suggest that the region "I" of the crust has been affected by alteration processes. First, sample

536 ZEP2-DR05-04 consists of $25 \mathrm{~mm}$ thick Fe-Mn crusts attached to a brecciated basalt substrate

537 mixed with phosphorites and carbonates. Hence, it is possible that continuous circulation of

538 fluids occurred through fractures from the underlying substrate. Fluid circulation would

539 continuously bring seawater-derived Be with higher ${ }^{10} \mathrm{Be} /{ }^{9} \mathrm{Be}$ ratios (i.e., present-day ${ }^{10} \mathrm{Be} /{ }^{9} \mathrm{Be}$

540 ratio) thus producing the anomalous Be isotope composition in region "I" of the crust.

541 Substantial alteration and reprecipitation of Mn-oxides phases at the expense of Fe-oxides

542 would have also promoted the observed enrichment in transition metals such as $\mathrm{Ni}, \mathrm{Cu}, \mathrm{Zn}$

543 due to their high affinities towards the Mn-phase.

544 One of the most striking feature observed in ZEP2-DR05-04 crust is the fractionation

545 of Ni isotopes towards lighter $\delta^{60 / 58} \mathrm{Ni}$ values at the bottom of the crust from 1.06 to $0.25 \%$,

546 which strongly correlate with the geochemical variations described above, in particular

547 decreasing $\mathrm{Mn} / \mathrm{Ni}$ ratios (Figure 7D). Four possible scenarios may account for such light Ni 
548 isotope compositions, (1) lighter Ni isotope composition of ambient seawater at the time of

549 crust formation, (2) meteoritic or basaltic/detrital inputs, (3) hydrothermal or halmyrolitic

550 inputs (i.e., alteration of the substrate by fluids on the seafloor), and (4) alteration and 551 reprecipitation processes of Mn-oxide phases.

552 A primary isotopic signal acquired from local seawater for explaining lighter $\mathrm{Ni}$

553 isotopes in the Fe-Mn crust would require either a change in the isotopic composition of local

554 sources of $\mathrm{Ni}$ or a change in the input and/or output fluxes of $\mathrm{Ni}$ in the oceans. A local source

555 would likely have affected the two Fe-Mn crusts collected at the same location, while a

556 change in the input and/or output fluxes in the oceans should have affected the four Fe-Mn

557 crusts collected in the same oceanic basin, i.e., the Pacific Ocean. Nonetheless, both

558 hypotheses are inconsistent with the Ni isotope composition of the three other Fe-Mn crusts,

559 which therefore rules out the possibility that light $\delta^{60 / 58} \mathrm{Ni}$ values in ZEP2-DR05-04 are a

560 primary signal from seawater.

561 Secondly, considering the ubiquitous occurrence of Fe-Ni cosmic spherules in South

562 Pacific Fe-Mn crusts (e.g., Kosakevitch, 1987; Halbach et al., 1989), the potential

563 contribution of meteoritic Ni should be evaluated. Nickel isotope compositions of iron

564 meteorites reported in previous studies yield a range of $\delta^{60 / 58} \mathrm{Ni}$ values from 0.24 and $0.36 \%$ o

565 (Moynier et al., 2007; Cook et al., 2008; Cameron et al., 2009; Gueguen et al., 2013).

566 However, iron meteorites such as Gibeon Iron (class IVA) and Nantan Iron (class IIICD) have

$567 \mathrm{Ni} / \mathrm{Fe}$ ratios of about 0.07 , which are similar to those obtained in the bottom section of crust

568 ZEP2-DR05-04. Hence, using simple mass balance considerations, it is unlikely that the entire

569 pool of $\mathrm{Ni}$ at the base of ZEP2-DR05-04 crust derived solely from meteoritic input.

570 As reported in Figure 7D, light $\delta^{60 / 58} \mathrm{Ni}$ values in ZEP2-DR05-04 crust correlate with

571 lower $\mathrm{Mn} / \mathrm{Ni}$ ratios $\left(\mathrm{R}^{2}=0.99\right.$; for the 5 subsamples at the bottom of the crust), implying

572 possible mixing relationships between typical hydrogenous $\mathrm{Ni}$ end-member $(\mathrm{Mn} / \mathrm{Ni} \sim 60$; 
$573 \delta^{60 / 58} \mathrm{Ni} \sim 1.8 \%$ ) and light $\delta^{60 / 58} \mathrm{Ni}$ values from the basaltic substrate (low $\mathrm{Mn} / \mathrm{Ni} ; \delta^{60 / 58} \mathrm{Ni} \sim 0$

$574 \%$; (Gall et al., 2012; Gueguen et al., 2013). However, the presence of detrital or volcanic

575 material can be discounted for explaining geochemical variations in ZEP2-DR05-04 crust.

576 Although Ti along with $\mathrm{Al}$ is often used as an indicator of the presence of detrital phases and

577 silicate-rich material in marine sediments, Koschinsky and Halbach (1995) showed that a

578 large proportion of $\mathrm{Ti}$ in hydrogenetic $\mathrm{Fe}-\mathrm{Mn}$ crusts is mainly derived from seawater as

579 colloidal Ti (i.e., uncharged Ti hydroxo-complexes adsorbed on the positively-charged Fe-

580 colloids) and is not controlled by detrital material. Addition of crustal material to the Fe-Mn

581 crust would have affected both $\mathrm{Al}$ and $\mathrm{Ti}$ enrichment in the crust in similar manners. $\mathrm{Al} / \mathrm{Fe}$

582 ratios are constant in ZEP2-DR05-04 crust while Ti/Al ratios decrease in the altered portion

583 of the crust (Table 1). The latter would be consistent with alteration of Fe-phases and loss of

584 Ti hosted in the Fe-phase to the fluid, implying that crustal Ni is unlikely to be the cause for

585 light $\delta^{60 / 58} \mathrm{Ni}$ values.

586 The third scenario, involving halmyrolitic reactions could potentially reconcile

587 isotopically light $\mathrm{Ni}$ isotopes, low $\mathrm{Mn} / \mathrm{Ni}$ ratios and anomalous Be isotope ratios.

588 Halmyrolysis has been described in volcanic context and is defined as low temperature

589 alteration of volcanic material by seawater (Staudigel and Hart, 1983; Staudigel et al., 1996).

590 Although limited data are available on $\mathrm{Ni}$ isotope fractionation during alteration of volcanic

591 rocks, preliminary study has shown that fresh and altered basalts have the same $\delta^{60 / 58} \mathrm{Ni}$ values

592 (Gueguen et al., 2013). In contrast, continental weathering of ultramafic complexes on land

593 has been shown to produce light $\mathrm{Ni}$ isotope enrichment in laterites, leading to preferential loss

594 of heavy Ni isotopes in the dissolved phase (Ratié et al., 2015), consistent with light Ni

595 isotopes being retained in Fe-oxides (Wasylenki et al., 2014b). Based on these results, one

596 should expect that halmyrolytic processes would promote the release of a non-fractionated to

597 heavy Ni isotope signature in the alteration fluids (i.e., relative to fresh basalt), which is not 
598 consistent with the light (i.e., near-zero) $\delta^{60 / 58} \mathrm{Ni}$ values observed in ZEP2-DR05-04 crust. As 599 discussed in Gall et al. (2013), lighter $\delta^{60 / 58} \mathrm{Ni}$ values down to $0.9 \%$ were interpreted as 600 reflecting hydrothermal inputs of $\mathrm{Ni}$, although no distinction was mentioned between low or 601 high-temperature processes. It is important to note however, that significant hydrothermal 602 inputs in Fe-Mn crusts would have increased Fe/Mn ratios (i.e., Chu et al., 2006) while adding 603 isotopically light $\mathrm{Ni}$ (i.e., near crustal values). This would have also resulted in significant 604 dilution of other transition metals, in particular Co (Manheim and Lanebostwick, 1988), 605 which is not observed here. Hence, we do not favor a potential hydrothermal or halmyrolitic 606 origin for the enrichment of $\mathrm{Ni}$ in this crust.

607 Finally, the fourth possible and favored scenario for explaining Ni isotope 608 fractionation is the effect of post-depositional alteration and reprecipitation of Mn-oxide 609 phases of the crust. Preliminary results suggest significant Ni isotope fractionation during Ni 610 sorption on Mn-oxides (e.g., birnessite; Gueguen, 2013; Wasylenki et al., 2014a). Data from 611 ZEP2-DR05-04 crust indicate large light $\mathrm{Ni}$ isotope fractionation towards light values (from 6121.08 to $0.25 \%$ ), supporting the assumption that Ni sorption to Mn-oxides surfaces in natural 613 deposits also fractionates Ni isotopes. Hence, our observations demonstrate that Ni sorption 614 on Mn-oxides is a fundamental process controlling $\mathrm{Ni}$ isotope fractionation in the natural 615 environment. Here, we propose that Mn-oxide alteration involving dissolution and 616 reprecipitation could explain $\mathrm{Ni}$ isotope variations without necessarily involving additional 617 inputs of Ni or change of seawater composition. The sharp increase in Ni/Mn ratios (Figure 4) 618 without a concomitant decrease in $\mathrm{Co} / \mathrm{Mn}$ ratios in region "I" of the crust (Figure 5) argue 619 against an initial rapid precipitation of Mn-oxides from seawater during formation of the 620 crust, and therefore hydrothermal input which would have resulted in lowering $\mathrm{Co} / \mathrm{Mn}$ ratios 621 (Manheim and Lanebostwick, 1988). In addition, $\delta^{60 / 58} \mathrm{Ni}$ values are not correlated with $622 \mathrm{Co} / \mathrm{Mn}$ ratios (Figure 7). The strong enrichment in Ni may be explained by a two-step model, 
623 by which $\mathrm{Ni}$ is first adsorbed or incorporated in primary Mn-oxides phases, then release in

624 porewater during the alteration stage and then reprecipitated in open system. In this case, the

625 full expression of $\mathrm{Ni}$ isotope (i.e., probably more than $1.1 \%$ relative to seawater, which is

626 still lower than experimental values of $>2 \%$; Gueguen, 2013; Wasylenki et al., 2014a) is

627 recorded in the crust resulting in unexpectedly light $\delta^{60 / 58} \mathrm{Ni}$ values compared to the average

628 value of the Fe-Mn crust $\left(\sim 1.8 \%\right.$ ). This scenario is also consistent with ${ }^{10} \mathrm{Be} /{ }^{9} \mathrm{Be}$ ratios since

629 abnormal values are also probably the result of re-equilibration with surrounding seawater or

630 alteration fluids (i.e., open system reprecipitation).

631 In summary, we interpret the light $\mathrm{Ni}$ isotope compositions of crust ZEP2-DR05-04 as

632 the result of fractionation from a source having a Ni isotope composition akin to that of

633 seawater, i.e., 1.4\%o (Cameron and Vance, 2014), during adsorption reactions and late-

634 stage alteration processes. We consider sorption processes as being important drivers of $\mathrm{Ni}$

635 isotope variations in Fe-Mn crusts, in addition to varying Ni isotope composition in seawater.

636

637 4.3. Temporal Ni isotopes record in Fe-Mn crusts and implications for paleoceanography

638

Prior to interpreting Ni isotope profile in Fe-Mn crust, it is crucial to first assess the

640 effect of diffusion processes, which could explain the homogenous Ni isotope composition in

641 Fe-Mn crusts. In-situ diffusion rate of Ni along the whole section of the crust can be

642 determined according to the equations from Henderson and Burton (1999). The distribution

643 coefficient of a given element is calculated as of the concentration in the surface of the crust

644 and in seawater, which is then compared with the diffusivity and the distribution coefficient of

645 uranium $\left(\mathrm{D}^{\mathrm{X}}\right.$ eff $=\left(\mathrm{D}^{\mathrm{U}}{ }_{\text {eff }} \mathrm{K}_{\text {crust }}^{\mathrm{U}}\right) / \mathrm{K}^{\mathrm{X}}$ crust, where $\mathrm{D}_{\text {eff }}$ are the effective diffusivities and $\mathrm{K}_{\text {crust }}$ are

646 the distribution coefficients of element $\mathrm{X}$ and uranium (U)). Using this approach, we obtain a

647 diffusion rate on the order of $\sim 10^{-9} \mathrm{~cm}^{2} /$ year which is slow enough compared to crust growth 
648 rate so we can reasonably assume that $\mathrm{Ni}$ does not diffuse in Fe-Mn crusts. Hence, diffusion

649 processes will not disturb Ni isotope composition in Fe-Mn crusts and pristine isotope

650 composition should be preserved at the sampling scale carried out in this study.

651 Although the concentration of $\mathrm{Ni}$ varies in the water column due to its nutrient-type 652 behavior, the relatively long oceanic residence time of Ni of $\sim 10-30,000$ yrs (Sclater et al., 653 1976; Bruland and Lohan, 2003; Gall et al., 2013; Cameron and Vance, 2014) in comparison 654 to the $\sim 1,500$ yrs mixing time of oceans, likely implies that Ni distribution in deep waters is 655 relatively well-mixed and homogenous. Nickel isotope profiles in the Pacific, Atlantic and 656 Southern Ocean water columns do not show any variations with depth (Cameron and Vance, 657 2014), thus we can reasonably presume that $\mathrm{Ni}$ isotopes are homogenous in deep waters. At 658 steady state, the $\mathrm{Ni}$ isotope composition of seawater is controlled by the relative fluxes of $\mathrm{Ni}$ 659 inputs to the ocean (e.g., rivers, atmospheric deposits, hydrothermal sources) and Ni uptake 660 (e.g., authigenic sinks, organic matter burial). The riverine flux and the authigenic sink (i.e., 661 Ni scavenged in Mn-oxides phases) are respectively the main input and output fluxes of Ni in 662 the ocean (Gall et al., 2013; Cameron and Vance, 2014), implying that the modern marine Ni 663 isotope mass balance is controlled by the isotopic composition of these fluxes. Considering 664 the relatively long residence time of $\mathrm{Ni}$ in the deep ocean, changes of either Ni input or output 665 should have been recorded in both South and North Pacific crusts. In contrast, one may 666 presume that different $\mathrm{Ni}$ isotope records between Fe-Mn crusts from the same oceanic basin 667 would reflect either local sources, changes of $\mathrm{Ni}$ isotope fractionation factor between seawater 668 and Fe-Mn crusts or post-depositional processes.

669 With the exception of the lower section of the crust ZEP2-DR05-04 which we argue is 670 the result of post-depositional alteration processes (see the previous section 4.2), our results 671 show fairly homogenous Ni isotope compositions in Pacific Fe-Mn crusts over the last ca. 17

672 Ma (Figure 6). We obtained, within uncertainties, similar average $\delta^{60 / 58} \mathrm{Ni}$ values of 1.72 
$673 \pm 0.18 \% \circ(2 \mathrm{sd})$ and $1.87 \pm 0.10 \% \circ(2 \mathrm{sd})$ in the South Pacific, and $1.65 \pm 0.19 \% \circ(2 \mathrm{sd})$ and 1.79

$674 \pm 0.13 \%$ (2sd) in the North Pacific, thus confirming limited $\mathrm{Ni}$ isotope variations over the last

$67517 \mathrm{Ma}$ and between different locations in the Pacific Ocean. By combining the four profiles

676 from our study with the CD29-2 profile of Gall et al. (2013), we reconstructed a complete

677 record of Ni isotope variations in seawater over the last $\sim 80 \mathrm{Ma}$ (Figure 8 ). Besides the light

$678 \mathrm{Ni}$ isotope excursion occurring around 48-50 Ma in CD29-2, there is no change in the average

679 oceanic $\delta^{60 / 58} \mathrm{Ni}$ value during the last $\sim 80 \mathrm{Ma}$. This result is important since important oceanic

680 changes (e.g., closing of the Panama gateway, onset of the Northern Hemisphere glaciation)

681 occurred during that period, but didn't produce changes of $\mathrm{Ni}$ isotope composition of seawater

682 remains fairly constant during the Cenozoic.

683 The negative Ni isotope excursion observed in CD29-2 Fe-Mn crust (Figure 8) by Gall

684 et al. (2013) and attributed to inputs from hydrothermal sources in the water column, could in

685 fact be the result of $\mathrm{Ni}$ isotope fractionation during precipitation and formation processes

686 occurring either in the water column or during formation of the crust, as we have

687 demonstrated for one of our Fe-Mn crusts. The flux of Ni from deep-sea hydrothermal vents

688 is poorly constrained so far (Cameron and Vance, 2014; Little et al., 2015), hence it is unclear

689 how Ni isotope variations in Fe-Mn crusts would respond to hydrothermal input. If lighter Ni

690 isotope compositions are indeed related to hydrothermal inputs, other isotopic proxies and

691 possibly Fe isotopes should also be influenced, which warrant additional studies of other

692 metal isotope systematics in Fe-Mn crusts.

693

694 5. Conclusions

695

696 In this study we have reported the geochemical composition and Ni isotope

697 composition of four hydrogenetic Fe-Mn crusts from the North and South Pacific oceans. 
698 Recent Ni isotope compositions reported for hydrogenetic Fe-Mn crusts suggested that Ni

699 isotopes could be used as a tracer of metal sources in modern oceans in particular

700 hydrothermal sources. Here, we demonstrated that Ni isotopes could also be fractionated due

701 to local effects such as alteration processes producing a range of $\mathrm{Ni}$ isotope compositions

702 encompassing the total range of $\delta^{60 / 58} \mathrm{Ni}$ values measured in Fe-Mn crusts so far. One of the

703 Fe-Mn crusts from the South Pacific presents unusual geochemical variations including high

$704 \mathrm{Mn}$ and Ni contents, anomalously high ${ }^{10} \mathrm{Be} /{ }^{9} \mathrm{Be}$ ratios, and light $\delta^{60 / 58} \mathrm{Ni}$ values in the range

705 of 1.08 to $0.25 \%$ o for subsamples close to or in contact with the altered substrate. These

706 results suggest that post-depositional processes involving alteration and reprecipitation

707 processes of Mn-rich oxide phases as well as substrate-seawater interactions have locally

708 affected the geochemical composition of the bottom of the crust. We argue that seawater

709 circulation through fractures within the substrate explains the anomalously high ${ }^{10} \mathrm{Be} /{ }^{9} \mathrm{Be}$

710 ratios in the crust, while rapid reprecipitation of Mn-oxides would have produced large Ni

711 isotope fractionation and preferential incorporation of metals with strong affinity for Mn (e.g.,

$712 \mathrm{Ni}, \mathrm{Cu}$ and $\mathrm{Co}$ ). We show that despite a light $\mathrm{Ni}$ isotope excursion at $\sim 48-50 \mathrm{Ma}$ in one

713 Pacific Fe-Mn crust published in another study, all Ni isotope data obtained so far including

714 our new dataset indicate that the mean $\delta^{60 / 58} \mathrm{Ni}$ value in Pacific Fe-Mn crusts has remained

715 constant at $\sim 1.8 \%$ o suggesting limited $\mathrm{Ni}$ isotope variations of seawater through the Cenozoic.

716 The lack of systematic change in the average $\delta^{60 / 58} \mathrm{Ni}$ value of seawater over the last $\sim 80 \mathrm{Ma}$

717 and the fact that secondary processes involving Ni sorption reactions on Fe-Mn oxides can

718 produce light $\mathrm{Ni}$ isotope excursion in Fe-Mn crusts, calls for a critical re-evaluation of the use

719 of $\mathrm{Ni}$ isotopes as paleoceanographic proxies. Although we cannot completely rule out the

720 influence of hydrothermal inputs and local sources on the Ni isotope composition of deep

721 seawater and more generally of the effect of variable Ni sources as previously suggested, our

722 results emphasize that enrichment processes and rates of precipitation are likely to be 
723 important if not the main factors controlling $\mathrm{Ni}$ isotope variations in oceanic Fe-Mn deposits.

724 Our results confirm recent experimental data showing that Ni isotopes fractionate during

725 sorption on Fe- and Mn-oxyhydroxides (Gueguen et al., 2011; Sorensen et al., 2011;

726 Gueguen, 2013; Wasylenki et al., 2014a; Wasylenki et al., 2015). Our results have also

727 implications for interpretation of $\mathrm{Ni}$ isotope variations in metalliferous sediments in the deep

728 geological time (e.g., Precambrian Banded Iron Formations) as we showed that precipitated-

729 recrystallization processes may overprint primary Ni isotope systems. The Ni isotope

730 composition of hydrothermal fluids and hydrothermal deposits and whether local Ni sources

731 (e.g., rivers and hydrothermal vents) may be recorded in the Ni isotope composition of Fe-Mn

732 crusts should be also explored in future studies.

733

734 Acknowledgments:

735 We thank Philippe Fernagu (Ifremer, Brest, France) for his help during preparation of

736 Fe-Mn crusts samples for microdrilling and Didier Bourlès (CEREGE, Université d'Aix-

737 Marseille, France) for Be isotope analyses. We thank the ROV Jason-II pilots and the crews

738 of the RV Kilo Moana for assistance with deployments and sample collection during the

739 cruise. We also thank the Microbial Observatory Project (FeMO) Principle Investigators:

740 Katrina Edwards (USC), Dave Emerson (Bigelow), Craig Moyer (WWU), Hubert Staudigel

741 (UCSD-SIO), and Brad Tebo (OHSU) for their support and input during cruise operations.

742 Support was provided by the LabexMer ANR-10-LABX-19-01, Europole Mer and FP7

743 (\#247837) grant.

744

$745 \quad$ Figure captions:

746 
747 Figure 1: Locations of the sampling sites (A) and photographs of North Pacific Fe-Mn crusts

748 sampling (B and C) using ROV Jason2 during FeMO cruise 2009 on the R/V Kilo Moana

749 (University of Hawaii). Photographs are courtesy of Woods Hole Oceanographic Institution.

750 The map (A) was generated with GeoMapApp (http://www.geomapapp.org/).

751

752 Figure 2: Photographs of the four Fe-Mn crusts samples after microdrill sampling using a

753 microdrilling device. Labels "top", "middle", and "bottom" are specified for each Fe-Mn

754 crust. "Top" corresponds to the surface in contact with seawater, "middle" is the part of the

755 crust towards the substrate and "bottom" is when the crust was collected with its substrate,

756 and thus it corresponds to the contact between the crust and substrate. Yellow dashed lines

757 correspond to the positions drilled for making one sample per line drilled. Regions "I" and

758 “O” of crust ZEP2-DR05-04 (D) are noted, and description of these regions are provided in 759 the text.

760

761 Figure 3: Ternary diagram plotting Fe, $\mathrm{Mn}$ and $(\mathrm{Ni}+\mathrm{Cu}+\mathrm{Co})$ x 10 concentrations of Fe-Mn

762 crusts from the North Pacific (Apuupuu Seamount) J2-480 and J2-480-R14, and Fe-Mn crusts

763 from the South Pacific (Austral archipelago of French Polynesia) ZEP2-DR05-04 and ZEP2-

764 DR06-03. Lines plotted between points represent the time-series of each Fe-Mn crust. The

765 diagram is adapted from Bonatti et al. (1972) and shows the three fields in which Fe-Mn rich

766 deposits are commonly classified: hydrothermal (light brown area), hydrogenetic (blue area)

767 and diagenetic (yellow area).

768

769 Figure 4: Elemental ratios of $\mathrm{Fe} / \mathrm{Mn}, \mathrm{Co} / \mathrm{Mn}, \mathrm{Ni} / \mathrm{Mn}$ and $\mathrm{Cu} / \mathrm{Mn}(\mathrm{g} / \mathrm{g})$ versus depth $(\mathrm{mm})$ in

770 the crust from South Pacific (Austral Archipelago of French Polynesia): ZEP2-DR05-04 and

771 ZEP2-DR06-03 and North Pacific (Apuupuu Seamount). Increasing Ni/Mn in this region "I" 
772 in comparison to other part of the crust and to crust ZEP2-DR06-03 indicate that it has

773 undergone geochemical perturbations probably as a result of fluid circulation in the substrate.

774 Increasing $\mathrm{Ni} / \mathrm{Mn}$ in four data points of crust ZEP2-DR-05-04 are likely not related to

775 variations in growth rates as illustrated by the lack of variations in $\mathrm{Fe} / \mathrm{Mn}(\mathrm{A})$ and $\mathrm{Co} / \mathrm{Mn}(\mathrm{E})$ 776 ratios.

777

778 Figure 5: Plots of the logarithm of ${ }^{10} \mathrm{Be} /{ }^{9} \mathrm{Be}$ ratios vs depth in South Pacific (Austral

779 Archipelago of French Polynesia) crusts (A and C) and in North Pacific (Apuupuu Seamount)

780 Fe-Mn crusts (B and D). The red lines in plots A and C show the limit between region "O"

781 (outer) from region "I" (inner) in crust ZEP2-DR05-04 (see text for ample descriptions).

782 Anomalously high ${ }^{10} \mathrm{Be} /{ }^{9} \mathrm{Be}$ ratios in region "I" of crust ZEP2-DR05-04 (A) likely indicate

783 that seawater fluids circulation in the substrate with high Be isotopes ratios affected the crust

784 directly in contact with the substrate. These fluids promoted alteration of Mn-oxides.

785

786

787

788

789

790

791

792 Figure 7: Nickel isotope composition (\%o) versus (A) P/Mn, (B) P/Ni, (C) Co/Mn and (D)

$793 \mathrm{Mn} / \mathrm{Ni}$ ratios $(\mathrm{g} / \mathrm{g})$ in the four Fe-Mn crusts. Symbols are for the same as in Figures 4, 5 and 6.

794 The green line in plot (D) represents the linear fitting for the last 5 subsamples of ZEP2-DR-

795

796

Figure 6: Ni isotope composition (\%o) of the Fe-Mn crusts versus depth in the crust. The four Fe-Mn crusts display similar average pattern, with the exception of crust ZEP2-DR05-04 showing a decrease in $\delta^{60 / 58} \mathrm{Ni}$ values from an average of $\sim 1.8 \%$ o to a value of $0.25 \%$ from $\sim 17 \mathrm{~mm}$ to $\sim 22 \mathrm{~mm}$ in the crust. The 2 sd error shown for our samples on the figure is based on replicate measurements of several geological reference materials (GRMs). 05-04 crust towards the bottom indicating a clear correlation between light Ni isotope compositions and low $\mathrm{Mn} / \mathrm{Ni}$ ratios, suggesting mixing between two end-members. These 
797 end-members are presumably a hydrogenetic component represented by the average $\delta^{60 / 58} \mathrm{Ni}$ 798 value of Fe-Mn crusts from the South Pacific of $1.76 \pm 0.23 \%$ (2sd) and the $\delta^{60 / 58} \mathrm{Ni}$ value of 799 a fluid similar to the substrate (i.e., basalt) in which it has circulated with a value of $\sim 0 \%$.

800

801 Figure 8: Time-series of the Ni isotope composition (\%o) of South Pacific (Austral 802 Archipelago of French Polynesia) and North Pacific (Apuupuu Seamount) Fe-Mn crusts and 803 the CD29-2 crust profile from Gall et al. (2013). Symbols are identical to those in Figures 4 804 and 5 for samples from this study and grey triangles represent the CD29-2 crust profile. The 805 blue band represents the range of $\delta^{60 / 58} \mathrm{Ni}$ values for modern seawater. Nickel isotope 806 composition is constant and similar within uncertainty in our three Fe-Mn crusts from both 807 North and South Pacific Oceans. The combination of our isotopic profiles from $\sim 0$ to $\sim 17 \mathrm{Ma}$ 808 and the CD29-2 profile from $\sim 8 \mathrm{Ma}$ to $\sim 75 \mathrm{Ma}$ implying shows that despite some small $\mathrm{Ni}$ 809 isotope excursions the average $\mathrm{Ni}$ isotope composition of Pacific deep waters has not varied 810 through Cenozoic and remains at a mean $\delta^{60 / 58} \mathrm{Ni}$ value of $\sim 1.8 \%$. The 2 sd error shown for 811 our samples on the figure is based on measurements of GRMs replicate.

812

813

Table captions:

814

815 Table 1: Elemental concentrations ( $\mu \mathrm{g} / \mathrm{g}$ or $\mathrm{wt} \%$ ) and elemental ratios $(\mathrm{g} / \mathrm{g})$, and Ni isotope 816 composition (\%o) of North Pacific (Apuupuu) and South Pacific (Tahiti) Fe-Mn crusts.

817

818 Table 2: ${ }^{10} \mathrm{Be} /{ }^{9} \mathrm{Be}$ ratios, ${ }^{9} \mathrm{Be}$ concentrations $(\mu \mathrm{g} / \mathrm{g}), \mathrm{Co} / \mathrm{Mn}$ ratios $(\mathrm{g} / \mathrm{g})$, age $(\mathrm{Ma})$ and growth 819 rates (mm/Ma) of Fe-Mn crusts from North Pacific (Apuupuu) and South Pacific (Tahiti). 


\section{References}

Abouchami, W., Goldstein, S.L., Galer, S.J.G., Eisenhauer, A. and Mangini, A. (1997) Secular changes of lead and neodymium in central Pacific seawater recorded by a Fe-Mn crust. Geochimica Et Cosmochimica Acta 61, 3957-3974.

Adam, C. and Bonneville, A. (2008) No thinning of the lithosphere beneath northern part of the CookAustral volcanic chains. Journal of Geophysical Research: Solid Earth 113, n/a-n/a.

Amend, J.P., McCollom, T.M., Hentscher, M. and Bach, W. (2011) Catabolic and anabolic energy for chemolithoautotrophs in deep-sea hydrothermal systems hosted in different rock types. Geochimica Et Cosmochimica Acta 75, 5736-5748.

Anbar, A.D. and Rouxel, O. (2007) Metal stable isotopes in paleoceanography. Annual Review of Earth and Planetary Sciences 35, 717-746.

Aplin, A.C. and Cronan, D.S. (1985) Ferromanganese oxide deposits from the Central Pacific ocean. 1. Encrustations from the Line islands archipelago. Geochimica Et Cosmochimica Acta 49, 427-436.

Arnold, M., Merchel, S., Bourlès, D.L., Braucher, R., Benedetti, L., Finkel, R.C., Aumaître, G., Gottdang, A. and Klein, M. (2010) The French accelerator mass spectrometry facility ASTER: Improved performance and developments. Nuclear Instruments and Methods in Physics Research Section B: Beam Interactions with Materials and Atoms 268, 1954-1959.

Barling, J., Arnold, G.L. and Anbar, A.D. (2001) Natural mass-dependent variations in the isotopic composition of molybdenum. Earth and Planetary Science Letters 193, 447-457.

Bau, M., Schmidt, K., Koschinsky, A., Hein, J., Kuhn, T. and Usui, A. (2014) Discriminating between different genetic types of marine ferro-manganese crusts and nodules based on rare earth elements and yttrium. Chemical Geology 381, 1-9.

Bonatti, E. and Joensuu, O. (1966) Deep-sea iron deposit from South Pacific. Science 154, 643-\&.

Bonatti, E., Kraemer, T. and Rydell, H. (1972) Classification and genesis of submarine ironmanganese deposits, Ferromanganese deposits on the Ocean Floor, D. Horn ed. Washington DC, Nat. Sci. Found., pp. 149-165.

Bonneville, A., Dosso, L. and Hildenbrand, A. (2006) Temporal evolution and geochemical variability of the South Pacific superplume activity. Earth and Planetary Science Letters 244, 251-269.

Bourles, D., Raisbeck, G.M. and Yiou, F. (1989) ${ }^{10} \mathrm{Be}$ and ${ }^{9} \mathrm{Be}$ in marine sediments and their potential for dating. Geochimica Et Cosmochimica Acta 53, 443-452.

Bruland, K.W. (1980) Oceanographic distributions of Cadmium, Zinc, Nickel, and Copper in the North Pacific. Earth and Planetary Science Letters 47, 176-198.

Bruland, K.W. (1983) Trace elements in sea water. Academic Press, London.

Bruland, K.W. and Lohan, M.C. (2003) Controls of Trace Metals in Seawater, in: Heinrich, D.H., Karl, K.T. (Eds.), Treatise on Geochemistry. Pergamon, Oxford, pp. 23-47.

Bruland, K.W., Orians, K.J. and Cowen, J.P. (1994) Reactive trace metals in the stratified central North Pacific. Geochimica Et Cosmochimica Acta 58, 3171-3182. 
Bryan, A.L., Dong, S., Wilkes, E.B. and Wasylenki, L.E. (2015) Zinc isotope fractionation during adsorption onto Mn oxyhydroxide at low and high ionic strength. Geochimica et Cosmochimica Acta $157,182-197$.

Cameron, V. and Vance, D. (2014) Heavy nickel isotope compositions in rivers and the oceans. Geochimica Et Cosmochimica Acta 128, 195-211.

Cameron, V., Vance, D., Archer, C. and House, C.H. (2009) A biomarker based on the stable isotopes of nickel. Proceedings of the National Academy of Sciences of the United States of America 106, 10944-10948.

Chen, T.-Y., Ling, H.-F., Hu, R., Frank, M. and Jiang, S.-Y. (2013) Lead isotope provinciality of central North Pacific Deep Water over the Cenozoic. Geochemistry, Geophysics, Geosystems 14, 1523-1537.

Chu, N.C., Johnson, C.M., Beard, B.L., German, C.R., Nesbitt, R.W., Frank, M., Bohn, M., Kubik, P.W., Usui, A. and Graham, I. (2006) Evidence for hydrothermal venting in Fe isotope compositions of the deep Pacific Ocean through time. Earth and Planetary Science Letters 245, 202-217.

Conway, T.M. and John, S.G. (2014) Quantification of dissolved iron sources to the North Atlantic Ocean. Nature 511, 212-215.

Cook, D.L., Clayton, R.N., Wadhwa, M., Janney, P.E. and Davis, A.M. (2008) Nickel isotopic anomalies in troilite from iron meteorites. Geophysical Research Letters 35, L01203.

Craig, J.D., Andrews, J.E. and Meylan, M.A. (1982) Ferromanganese deposits in the hawaiian archipelago. Marine Geology 45, 127-157.

De Carlo, E.H., McMurtry, G.M. and Kim, K.H. (1987) Geochemistry of ferromanganese crusts from the hawaiian archipelago. 1. Northern survey areas. Deep-Sea Research Part a-Oceanographic Research Papers 34, 441-467.

Fitzsimmons, J.N., Boyle, E.A. and Jenkins, W.J. (2014) Distal transport of dissolved hydrothermal iron in the deep South Pacific Ocean. Proceedings of the National Academy of Sciences 111, 1665416661.

Frank, M. (2002) Radiogenic isotopes: Tracers of past ocean circulation and erosional input. Reviews of Geophysics 40.

Frank, M., O'Nions, R.K., Hein, J.R. and Banakar, V.K. (1999) 60 Myr records of major elements and $\mathrm{Pb}-\mathrm{Nd}$ isotopes from hydrogenous ferromanganese crusts: reconstruction of seawater paleochemistry. Geochimica Et Cosmochimica Acta 63, 1689-1708.

Frank, M., Whiteley, N., Kasten, S., Hein, J.R. and O'Nions, K. (2002) North Atlantic deep water export to the Southern Ocean over the past 14 Myr: Evidence from $\mathrm{Nd}$ and $\mathrm{Pb}$ isotopes in ferromanganese crusts. Paleoceanography 17.

Fujii, T., Moynier, F., Dauphas, N. and Abe, M. (2011) Theoretical and experimental investigation of nickel isotopic fractionation in species relevant to modern and ancient oceans. Geochimica et Cosmochimica Acta 75, 469-482.

Gall, L., Williams, H., Siebert, C. and Halliday, A. (2012) Determination of mass-dependent variations in nickel isotope compositions using double spiking and MC-ICPMS. Journal of Analytical Atomic Spectrometry 27, 137-145. 
Gall, L., Williams, H.M., Siebert, C., Halliday, A.N., Herrington, R.J. and Hein, J.R. (2013) Nickel isotopic compositions of ferromanganese crusts and the constancy of deep ocean inputs and continental weathering effects over the Cenozoic. Earth and Planetary Science Letters 375, 148-155.

Gueguen, B. (2013) Apport de la géochimie isotopique du Nickel à l'étude des dépôts métallifères océaniques. Thesis, University of Brest.

Gueguen, B., Rouxel, O., Ponzevera, E., Bekker, A. and Fouquet, Y. (2013) Nickel Isotope Variations in Terrestrial Silicate Rocks and Geological Reference Materials Measured by MC-ICP-MS. Geostandards and Geoanalytical Research 37, 297-317.

Gueguen, B., Rouxel, O., Ponzevera, E., Sorensen, J., Toner, B. and Bekker, A. (2011) Ni biogeochemical cycle through geological time: insights from $\mathrm{Ni}$ isotope variations in modern and ancient marine metallifereous deposits, AGU Fall Meeting Abstracts, p. 1845.

Halbach, P., Kriete, C., Prause, B. and Puteanus, D. (1989) Mechanisms to explain the platinum concentration in ferromanganese seamount crusts. Chemical Geology 76, 95-106.

Halbach, P. and Puteanus, D. (1984) The influence of the carbonate dissolution rate on the growth and composition of Co-rich ferromanganese crusts from Central Pacific seamount areas. Earth and Planetary Science Letters 68, 73-87.

Halbach, P., Puteanus, D. and Manheim, F.T. (1984) Platinum concentrations in ferromanganese seamount crusts from the Central Pacific. Naturwissenschaften 71, 577-579.

Halbach, P., Segl, M., Puteanus, D. and Mangini, A. (1983) Co-fluxes and growth rates in ferromanganese deposits from Central Pacific seamount areas. Nature 304, 716-719.

Hein, J.R., Bohrson, W.A., Schulz, M.S., Noble, M. and Clague, D.A. (1992) Variations in the finescale composition of a Central Pacific ferromanganese crust: paleoceanographic implications. Paleoceanography 7, 63-77.

Hein, J.R., Conrad, T.A., Frank, M., Christl, M. and Sager, W.W. (2012) Copper-nickel-rich, amalgamated ferromanganese crust-nodule deposits from Shatsky Rise, NW Pacific. Geochem. Geophys. Geosyst. 13, Q10022.

Hein, J.R. and Koschinsky, A. (2014) Deep-Ocean Ferromanganese Crusts and Nodules, in: Holland, H.D., Turekian, K.K. (Eds.), Treatise on Geochemistry (Second Edition). Elsevier, Oxford, pp. 273291.

Hein, J.R., Mizell, K., Koschinsky, A. and Conrad, T.A. (2013) Deep-ocean mineral deposits as a source of critical metals for high- and green-technology applications: Comparison with land-based resources. Ore Geology Reviews 51, 1-14.

Hein, J.R., Schwab, W.C. and Davis, A.S. (1988) Cobalt-rich and platinum-rich ferromanagenese crusts and associated substrate rocks from the Marshall islands. Marine Geology 78, 255-283.

Hein, J.R., Yeh, H.W., Gunn, S.H., Sliter, W.V., Benninger, L.M. and Wang, C.H. (1993) Two major Cenozoic episodes of phosphogenesis recorded in equatorial Pacific seamount deposits.

Paleoceanography 8, 293-311.

Henderson, G.M. and Burton, K.W. (1999) Using $\left({ }^{234} \mathrm{U}^{238} \mathrm{U}\right)$ to assess diffusion rates of isotope tracers in ferromanganese crusts. Earth and Planetary Science Letters 170, 169-179. 
Horner, T.J., Schonbachler, M., Rehkämper, M., Nielsen, S.G., Williams, H., Halliday, A.N., Xue, Z. and Hein, J.R. (2010) Ferromanganese crusts as archives of deep water Cd isotope compositions. Geochemistry Geophysics Geosystems 11, 1525-2027.

Horner, T.J., Williams, H.M., Hein, J.R., Saito, M.A., Burton, K.W., Halliday, A.N. and Nielsen, S.G. (2015) Persistence of deeply sourced iron in the Pacific Ocean. Proceedings of the National Academy of Sciences.

Kosakevitch, A. (1987) Platiniferous Fe-Ni cosmic spherules in a marine metalliferous incrustation from Tuamotu (French Polynesia). Comptes Rendus De l'Academie Des Sciences 305, 105-108.

Kosakevitch, A. and Disnar, J.R. (1997) Nature and origin of chemical zoning in the metal nucleus and oxide cortex of cosmic spherules from the Tuamotu Archipelago, French Polynesia. Geochimica Et Cosmochimica Acta 61, 1073-1082.

Koschinsky, A. and Halbach, P. (1995) Sequential leaching of marine ferromanganese precipitates: Genetic implications. Geochimica et Cosmochimica Acta 59, 5113-5132.

Koschinsky, A. and Hein, J.R. (2003) Uptake of elements from seawater by ferromanganese crusts: solid-phase associations and seawater speciation. Marine Geology 198, 331-351.

Koschinsky, A., Stascheit, A., Bau, M. and Halbach, P. (1997) Effects of phosphatization on the geochemical and mineralogical composition of marine ferromanganese crusts. Geochimica et Cosmochimica Acta 61, 4079-4094.

Ku, T.L., Kusakabe, M., Measures, C.I., Southon, J.R., Cusimano, G., Vogel, J.S., Nelson, D.E. and Nakaya, S. (1990) Beryllium isotope distribution in the western North Atlantic: a comparison to the Pacific. Deep-Sea Research Part a-Oceanographic Research Papers 37, 795-808.

Kyte, F.T., Leinen, M., Ross Heath, G. and Zhou, L. (1993) Cenozoic sedimentation history of the central North Pacific: Inferences from the elemental geochemistry of core LL44-GPC3. Geochimica et Cosmochimica Acta 57, 1719-1740.

Lebatard, A.-E., Bourlès, D.L., Duringer, P., Jolivet, M., Braucher, R., Carcaillet, J., Schuster, M., Arnaud, N., Monié, P., Lihoreau, F., Likius, A., Mackaye, H.T., Vignaud, P. and Brunet, M. (2008) Cosmogenic nuclide dating of Sahelanthropus tchadensis and Australopithecus bahrelghazali: MioPliocene hominids from Chad. Proceedings of the National Academy of Sciences 105, 3226-3231.

Lesuave, R., Pichocki, C., Pautot, G., Hoffert, M., Morel, Y., Voisset, M., Monti, S., Amosse, J. and Kosakevitch, A. (1989) Geological and mineralogical study of Co-rich ferromanganese crusts from a submerged atoll in the Tuamotu archipelago (French Polynesia). Marine Geology 87, 227-247.

Levasseur, S., Frank, M., Hein, J.R. and Halliday, A. (2004) The global variation in the iron isotope composition of marine hydrogenetic ferromanganese deposits: implications for seawater chemistry? Earth and Planetary Science Letters 224, 91-105.

Ling, H.-F., Jiang, S.-Y., Frank, M., Zhou, H.-Y., Zhou, F., Lu, Z.-L., Chen, X.-M., Jiang, Y.-H. and Ge, C.-D. (2005) Differing controls over the Cenozoic $\mathrm{Pb}$ and Nd isotope evolution of deepwater in the central North Pacific Ocean. Earth and Planetary Science Letters 232, 345-361.

Ling, H.F., Burton, K.W., O'Nions, R.K., Kamber, B.S., von Blanckenburg, F., Gibb, A.J. and Hein, J.R. (1997) Evolution of $\mathrm{Nd}$ and $\mathrm{Pb}$ isotopes in Central Pacific seawater from ferromanganese crusts. Earth and Planetary Science Letters 146, 1-12.

Little, S.H., Sherman, D.M., Vance, D. and Hein, J.R. (2014b) Molecular controls on Cu and Zn isotopic fractionation in Fe-Mn crusts. Earth and Planetary Science Letters 396, 213-222. 
Little, S.H., Vance, D., Lyons, T.W. and McManus, J. (2015) Controls on trace metal authigenic enrichment in reducing sediments: Insights from modern oxygen-deficient settings. American Journal of Science 315, 77-119.

Manheim, F.T. and Lanebostwick, C.M. (1988) Cobalt in ferromanganese crusts as a monitor of hydrothermal discharge on the Pacific seafloor. Nature 335, 59-62.

Morris, J.D. (1991) Applications of cosmogenic ${ }^{10} \mathrm{Be}$ to problems in the Earth sciences. Annual Review of Earth and Planetary Sciences 19, 313-350.

Moynier, F., Blichert-Toft, J., Telouk, P., Luck, J.M. and Albarede, F. (2007) Comparative stable isotope geochemistry of $\mathrm{Ni}, \mathrm{Cu}, \mathrm{Zn}$, and $\mathrm{Fe}$ in chondrites and iron meteorites. Geochimica $\mathrm{Et}$ Cosmochimica Acta 71, 4365-4379.

Nicholson, K., Hein, J.R., Buehn, B. and Dasgupta, S. (1997) Manganese mineralization; geochemistry and mineralogy of terrestrial and marine deposits. Geological Society of London : London, United Kingdom.

Nielsen, S.G., Gannoun, A., Marnham, C., Burton, K.W., Halliday, A.N. and Hein, J.R. (2011) New age for ferromanganese crust 109D-C and implications for isotopic records of lead, neodymium, hafnium, and thallium in the Pliocene Indian Ocean. Paleoceanography 26.

Nielsen, S.G., Wasylenki, L.E., Rehkämper, M., Peacock, C.L., Xue, Z. and Moon, E.M. (2013) Towards an understanding of thallium isotope fractionation during adsorption to manganese oxides. Geochimica Et Cosmochimica Acta 117, 252-265.

Nimmo, M., Van Den Berg, C.M.G. and Brown, J. (1989) The chemical speciation of dissolved nickel, copper, vanadium and iron in Liverpool Bay, Irish Sea. Estuarine Coastal and Shelf Science 29, 57-74.

Nishiizumi, K., Kohl, C.P., Arnold, J.R., Klein, J., Fink, D. and Middleton, R. (1991) Cosmic ray produced $10 \mathrm{Be}$ and $26 \mathrm{Al}$ in Antarctic rocks: exposure and erosion history. Earth and Planetary Science Letters 104, 440-454.

O'Nions, R.K., Frank, M., von Blanckenburg, F. and Ling, H.F. (1998) Secular variation of Nd and Pb isotopes in ferromanganese crusts from the Atlantic, Indian and Pacific Oceans. Earth and Planetary Science Letters 155, 15-28.

Peacock, C.L. (2009) Physiochemical controls on the crystal-chemistry of Ni in birnessite: Genetic implications for ferromanganese precipitates. Geochimica et Cosmochimica Acta 73, 3568-3578.

Peate, D.W., Falkena, L. and Kent, A.J.R. (2009) Pb isotope variations in hydrogenetic Fe-Mn crusts from the Izu-Bonin fore-arc. Chemical Geology 258, 288-298.

Pichocki, C. and Hoffert, M. (1987) Characteristics of Co-rich ferromanganese nodules and crusts sampled in French Polynesia. Marine Geology 77, 109-119.

Puteanus, D. and Halbach, P. (1988) Correlation of Co concentration and growth rate - A method for age determination of ferromanganese crusts. Chemical Geology 69, 73-85.

Ratié, G., Jouvin, D., Garnier, J., Rouxel, O., Miska, S., Guimarães, E., Cruz Vieira, L., Sivry, Y., Zelano, I., Montarges-Pelletier, E., Thil, F. and Quantin, C. (2015) Nickel isotope fractionation during tropical weathering of ultramafic rocks. Chemical Geology 402, 68-76. 
Rehkämper, M., Frank, M., Hein, J.R. and Halliday, A. (2004) Cenozoic marine geochemistry of thallium deduced from isotopic studies of ferromanganese crusts and pelagic sediments. Earth and Planetary Science Letters 219, 77-91.

Rehkämper, M., Frank, M., Hein, J.R., Porcelli, D., Halliday, A., Ingri, J. and Liebetrau, V. (2002) Thallium isotope variations in seawater and hydrogenetic, diagenetic, and hydrothermal ferromanganese deposits. Earth and Planetary Science Letters 197, 65-81.

Reynolds, B.C., Frank, M. and O'Nions, R.K. (1999) Nd- and Pb-isotope time series from Atlantic ferromanganese crusts: implications for changes in provenance and paleocirculation over the last 8 Myr. Earth and Planetary Science Letters 173, 381-396.

Rudnick, R.L. and Gao, S. (2014) Composition of the Continental Crust, in: Holland, H.D., Turekian, K.K. (Eds.), Treatise on Geochemistry (Second Edition). Elsevier, Oxford, pp. 1-51.

Schmitt, A.D., Galer, S.J.G. and Abouchami, W. (2009) Mass-dependent cadmium isotopic variations in nature with emphasis on the marine environment. Earth and Planetary Science Letters 277, 262-272.

Sclater, F.R., Boyle, E. and Edmond, J.M. (1976) On the marine geochemistry of nickel. Earth and Planetary Science Letters 31, 119-128.

Segl, M., Mangini, A., Bonani, G., Hofmann, H.J., Nessi, M., Suter, M., Wolfli, W., Friedrich, G., Pluger, W.L., Wiechowski, A. and Beer, J. (1984) ${ }^{10} \mathrm{Be}$-dating of a manganese crust from Central North Pacific and implications for ocean palaeocirculation. Nature 309, 540-543.

Siebert, C., Nagler, T.F. and Kramers, J.D. (2001) Determination of molybdenum isotope fractionation by double-spike multicollector inductively coupled plasma mass spectrometry. Geochemistry Geophysics Geosystems 2, 1032.

Siebert, C., Nagler, T.F., von Blanckenburg, F. and Kramers, J.D. (2003) Molybdenum isotope records as a potential new proxy for paleoceanography. Earth and Planetary Science Letters 211, 159-171.

Sorensen, J.V., Toner, B.M., Gueguen, B. and Rouxel, O. (2011) Ni Speciation and Isotope Fractionation in Marine Ferromangenese Deposits. Goldschmidt Conference 2011 75, 1914.

Staudigel, H. and Hart, S.R. (1983) Alteration of basaltic glass: Mechanisms and significance for the oceanic crust-seawater budget. Geochimica Et Cosmochimica Acta 47, 337-350.

Staudigel, H., Plank, A., White, B. and Schminke, H., -U., (1996) Geochemical fluxes during seafloor alteration of the basaltic upper oceanic crust : DSDP sites 417 and 418. Geophysical Monograph Series vol. 96, 19-38.

Steinhilber, F., Abreu, J.A., Beer, J., Brunner, I., Christl, M., Fischer, H., Heikkilä, U., Kubik, P.W., Mann, M., McCracken, K.G., Miller, H., Miyahara, H., Oerter, H. and Wilhelms, F. (2012) 9,400 years of cosmic radiation and solar activity from ice cores and tree rings. Proceedings of the National Academy of Sciences 109, 5967-5971.

Stuart, F.M. and Lee, M.R. (2012) Micrometeorites and extraterrestrial He in a ferromanganese crust from the Pacific Ocean. Chemical Geology 322-323, 209-214.

Tagliabue, A., Bopp, L., Dutay, J.C., Bowie, A.R., Chever, F., Jean-Baptiste, P., Bucciarelli, E., Lannuzel, D., Remenyi, T., Sarthou, G., Aumont, O., Gehlen, M. and Jeandel, C. (2010) Hydrothermal contribution to the oceanic dissolved iron inventory. Nature Geoscience 3, 252-256.

Tanaka, S. and Inoue, T. (1979) ${ }^{10} \mathrm{Be}$ of North Pacific sediment cores up to 2.5 million years BP. Earth and Planetary Science Letters 45, 181-187. 
Toner, B.M., Fakra, S.C., Manganini, S.J., Santelli, C.M., Marcus, M.A., Moffett, J., Rouxel, O., German, C.R. and Edwards, K.J. (2009) Preservation of iron(II) by carbon-rich matrices in a hydrothermal plume. Nature Geoscience 2, 197-201.

Turner, A., Nimmo, M. and Thuresson, K.A. (1998) Speciation and sorptive behaviour of nickel in an organic-rich estuary (Beaulieu, UK). Marine Chemistry 63, 105-118.

van de Flierdt, T., Frank, M., Halliday, A.N., Hein, J.R., Hattendorf, B., Günther, D. and Kubik, P.W. (2003) Lead isotopes in North Pacific deep water - implications for past changes in input sources and circulation patterns. Earth and Planetary Science Letters 209, 149-164.

van de Flierdt, T., Frank, M., Halliday, A.N., Hein, J.R., Hattendorf, B., Günther, D. and Kubik, P.W. (2004) Tracing the history of submarine hydrothermal inputs and the significance of hydrothermal hafnium for the seawater budget-a combined $\mathrm{Pb}-\mathrm{Hf}-\mathrm{Nd}$ isotope approach. Earth and Planetary Science Letters 222, 259-273.

Van Den Berg, C.M.G. and Nimmo, M. (1987) Determination of interactions of Nickel with dissolved organic material in seawater using cathodic stripping voltammetry. Science of the Total Environment 60, 185-195.

von Blanckenburg, F., O'Nions, R.K., Belshaw, N.S., Gibb, A. and Hein, J.R. (1996a) Global distribution of beryllium isotopes in deep ocean water as derived from Fe-Mn crusts. Earth and Planetary Science Letters 141, 213-226.

von Blanckenburg, F., O'Nions, R.K. and Hein, J.R. (1996b) Distribution and sources of preanthropogenic lead isotopes in deep ocean water from Fe-Mn crusts. Geochimica Et Cosmochimica Acta 60, 4957-4963.

Wasylenki, L., Wells, R. and Spivak-Birndorf, L. (2014a) Ni Sorption to Birnessite Drives a Surprisingly Large Fractionation, AGU Fall Meeting Abstracts, p. 3623.

Wasylenki, L.E., Howe, H.D., Spivak-Birndorf, L.J. and Bish, D.L. (2015) Ni isotope fractionation during sorption to ferrihydrite; Implications for $\mathrm{Ni}$ in banded iron formations. Chemical Geology 400, 56-64.

Wasylenki, L.E., Rolfe, B.A., Weeks, C.L., Spiro, T.G. and Anbar, A.D. (2008) Experimental investigation of the effects of temperature and ionic strength on Mo isotope fractionation during adsorption to manganese oxides. Geochimica Et Cosmochimica Acta 72, 5997-6005.

Wasylenki, L.E., Swihart, J.W. and Romaniello, S.J. (2014b) Cadmium isotope fractionation during adsorption to Mn oxyhydroxide at low and high ionic strength. Geochimica et Cosmochimica Acta $140,212-226$.

Wasylenki, L.E., Weeks, C.L., Bargar, J.R., Spiro, T.G., Hein, J.R. and Anbar, A.D. (2011) The molecular mechanism of Mo isotope fractionation during adsorption to birnessite. Geochimica Et Cosmochimica Acta 75, 5019-5031.

Willenbring, J.K. and von Blanckenburg, F. (2010a) Long-term stability of global erosion rates and weathering during late-Cenozoic cooling. Nature 465, 211-214.

Willenbring, J.K. and von Blanckenburg, F. (2010b) Meteoric cosmogenic Beryllium-10 adsorbed to river sediment and soil: Applications for Earth-surface dynamics. Earth-Science Reviews 98, 105-122.

Zhu, X.K., O'Nions, R.K., Guo, Y.L. and Reynolds, B.C. (2000) Secular variation of iron isotopes in North Atlantic Deep Water. Science 287, 2000-2002. 
Table 1: Elemental concentrations, elemental ratios, and Ni isotope composition of North Pacific (Apuupuu) and South Pacific (Tahiti) Fe-Mn crusts.

\begin{tabular}{|c|c|c|c|c|c|c|c|c|c|c|c|c|c|c|c|c|c|c|c|c|c|}
\hline Sample name & $\begin{array}{l}\text { Depth in } \\
\text { the crust } \\
(\mathrm{mm})\end{array}$ & Mn (wto) & $\mathrm{Fe}(w t \%)$ & Al $(\mu \mathrm{g} / \mathrm{g})$ & $\mathrm{Ti}(\mu \mathrm{g} / \mathrm{g})$ & Ca $(\mu \mathrm{g} / \mathrm{g})$ & $\mathrm{P}(\mu \mathrm{g} / \mathrm{g})$ & Co $(\mu \mathrm{g} / \mathrm{g})$ & $\mathrm{Ni}(\mu \mathrm{g} / \mathrm{g})$ & $\mathrm{Cu}(\mu \mathrm{g} / \mathrm{g})$ & $\mathrm{Zn}(\mu \mathrm{g} / \mathrm{g})$ & $\mathrm{Fe} / \mathrm{Mn}$ & $\mathrm{Ni} / \mathrm{Mn}$ & $\mathrm{Cu} / \mathrm{Mn}$ & $\mathrm{Zn} / \mathrm{Mn}$ & $\mathrm{Ni} / \mathrm{Co}$ & Ti/AI & $\mathrm{Al} / \mathrm{Fe}$ & P/Ni & $\delta^{60 / 58} \mathrm{Ni}(\% \circ)$ & 2se (\%) \\
\hline \multicolumn{22}{|c|}{ ZEP2-DR05-04 Fe-Mn crust } \\
\hline Average & & 10.31 & 8.36 & 3996 & 7693 & 14466 & 3646 & 5462 & 2002 & 548 & 345 & & & & & & & & & 1.72 & $0.17(2 \mathrm{sd})$ \\
\hline ZEP2-DR05-04-L1 & 0.5 & 17.07 & 8.95 & 3604 & 11864 & 17876 & 3662 & 12406 & 2790 & 383 & 395 & 0.52 & 0.016 & 0.0022 & 0.0023 & 0.22 & 3.29 & 0.04 & 1.31 & 1.89 & 0.04 \\
\hline ZEP2-DR05-04-L2 & 1 & 13.53 & 8.12 & 2809 & 9051 & 14012 & 2386 & 8922 & 2483 & 410 & 335 & 0.60 & 0.018 & 0.0030 & 0.0025 & 0.28 & 3.22 & 0.03 & 0.96 & 1.82 & 0.05 \\
\hline ZEP2-DR05-04-L3 & 2.5 & 15.71 & 8.77 & 3998 & 10937 & 15973 & 3230 & 8495 & 2919 & 564 & 417 & 0.56 & 0.019 & 0.0036 & 0.0027 & 0.34 & 2.74 & 0.05 & 1.11 & 1.69 & 0.03 \\
\hline ZEP2-DR05-04-L4 & 3.5 & 11.02 & 7.23 & 3351 & 8808 & 12023 & 2334 & 5536 & 2063 & 435 & 327 & 0.66 & 0.019 & 0.0040 & 0.0030 & 0.37 & 2.63 & 0.05 & 1.13 & 1.71 & 0.03 \\
\hline ZEP2-DR05-04-L5 & 4.5 & 7.37 & 6.59 & 2868 & 6520 & 8593 & 1944 & 3047 & 1287 & 328 & 229 & 0.89 & 0.017 & 0.0044 & 0.0031 & 0.42 & 2.27 & 0.04 & 1.51 & 1.65 & 0.02 \\
\hline ZEP2-DR05-04-L6 & 6.5 & 8.33 & 7.96 & 3697 & 7181 & 10927 & 2838 & 3750 & 1259 & 422 & 261 & 0.95 & 0.015 & 0.0051 & 0.0031 & 0.34 & 1.94 & 0.05 & 2.25 & 1.75 & 0.04 \\
\hline ZEP2-DR05-04-L7 & 8.5 & 12.76 & 11.90 & 4883 & 9760 & 19372 & 5969 & 5882 & 1919 & 674 & 414 & 0.93 & 0.015 & 0.0053 & 0.0032 & 0.33 & 2.00 & 0.04 & 3.11 & 1.74 & 0.03 \\
\hline ZEP2-DR05-04-L8 & 10 & 9.84 & 9.50 & 3917 & 7785 & 13743 & 4033 & 4782 & 1464 & 576 & 341 & 0.97 & 0.015 & 0.0059 & 0.0035 & 0.31 & 1.99 & 0.04 & 2.75 & 1.81 & 0.03 \\
\hline ZEP2-DR05-04-L9 & 11.5 & 9.32 & 8.62 & 3478 & 7014 & 17582 & 5784 & 4684 & 1365 & 545 & 316 & 0.93 & 0.015 & 0.0058 & 0.0034 & 0.29 & 2.02 & 0.04 & 4.24 & 1.72 & 0.03 \\
\hline ZEP2-DR05-04-L10 & 12.5 & 9.91 & 9.62 & 3208 & 6555 & 11675 & 2950 & 5483 & 1459 & 533 & 314 & 0.97 & 0.015 & 0.0054 & 0.0032 & 0.27 & 2.04 & 0.03 & 2.02 & 1.67 & 0.04 \\
\hline ZEP2-DR05-04-L11 & 13.5 & 8.19 & 8.30 & 2885 & 5669 & 10238 & 2574 & 4226 & 1240 & 476 & 260 & 1.01 & 0.015 & 0.0058 & 0.0032 & 0.29 & 1.97 & 0.03 & 2.08 & 1.63 & 0.03 \\
\hline ZEP2-DR05-04-L12 & 15.5 & 7.60 & 7.44 & 3558 & 5760 & 11681 & 2844 & 3952 & 1336 & 515 & 276 & 0.98 & 0.018 & 0.0068 & 0.0036 & 0.34 & 1.62 & 0.05 & 2.13 & 1.54 & 0.03 \\
\hline ZEP2-DR05-04-L13 & 16.5 & 7.33 & 7.69 & 3140 & 5436 & 11421 & 3131 & 3675 & 1188 & 465 & 248 & 1.05 & 0.016 & 0.0063 & 0.0034 & 0.32 & 1.73 & 0.04 & 2.64 & 1.69 & 0.02 \\
\hline ZEP2-DR05-04-L14 & 17.5 & 12.98 & 11.37 & 6809 & 9821 & 21638 & 6105 & 6346 & 2753 & 947 & 529 & 0.88 & 0.021 & 0.0073 & 0.0041 & 0.43 & 1.44 & 0.06 & 2.22 & 1.08 & 0.03 \\
\hline ZEP2-DR05-04-L15 & 19 & 7.48 & 6.95 & 3966 & 5251 & 14892 & 3748 & 3150 & 1871 & 555 & 337 & 0.93 & 0.025 & 0 & 0.0045 & 0.59 & 1.32 & 0.06 & 2.00 & 1.01 & 0.04 \\
\hline ZEP2-DR05-04-L16 & 20 & 10.13 & 7.99 & 6070 & 8280 & 17988 & 4239 & 5205 & 3238 & 810 & 473 & 0.79 & 0.032 & 0.0080 & 0.0047 & 0.62 & 1.36 & 0.08 & 1.31 & 0.63 & 0.04 \\
\hline ZEP2-DR05-04-L17 & 22 & 6.64 & 5.07 & 5694 & 5089 & 16289 & 4215 & 3321 & 3395 & 670 & 403 & 0.76 & 0.051 & 0.0101 & 0.0061 & 1.02 & 0.89 & 0.11 & 1.24 & 0.25 & 0.05 \\
\hline
\end{tabular}




\begin{tabular}{|c|c|c|c|c|c|c|c|c|c|c|c|c|c|c|c|c|c|c|c|c|c|}
\hline Sample name & $\begin{array}{l}\text { Depth in } \\
\text { the crust } \\
(\mathrm{mm})\end{array}$ & $\operatorname{Mn}(w t \%)$ & $\mathrm{Fe}(\mathrm{wt} \%)$ & Al $(\mu \mathrm{g} / \mathrm{g})$ & $\mathrm{Ti}(\mu \mathrm{g} / \mathrm{g})$ & $\mathrm{Ca}(\mu \mathrm{g} / \mathrm{g})$ & $P(\mu \mathrm{g} / \mathrm{g})$ & Co $(\mu \mathrm{g} / \mathrm{g})$ & $\mathrm{Ni}(\mu \mathrm{g} / \mathrm{g})$ & $\mathrm{Cu}(\mu \mathrm{g} / \mathrm{g})$ & $\mathrm{Zn}(\mu \mathrm{g} / \mathrm{g})$ & $\mathrm{Fe} / \mathrm{Mn}$ & $\mathrm{Ni} / \mathrm{Mn}$ & $\mathrm{Cu} / \mathrm{Mn}$ & $\mathrm{Zn} / \mathrm{Mn}$ & $\mathrm{Ni} / \mathrm{Co}$ & Ti/Al & $\mathrm{A} / \mathrm{Fe}$ & $\mathrm{P} / \mathrm{Ni}$ & $\delta^{60 / 58} \mathrm{Ni}(\% \circ)$ & 2se (\%) \\
\hline \multicolumn{22}{|c|}{ ZEP2-DR06-03 Fe-Mn crust } \\
\hline Average & & 8.78 & 8.23 & 3601 & 7586 & 44011 & 7707 & 4843 & 1248 & 473 & 257 & & & & & & & & & 1.87 & $0.10(2 \mathrm{sd})$ \\
\hline ZEP2-DR06-03-L1 & 0.5 & 11.41 & 7.87 & 2079 & 8037 & 12804 & 2923 & 8694 & 1682 & 293 & 255 & 0.69 & 0.015 & 0.0026 & 0.0022 & 0.19 & 3.87 & 0.03 & 1.74 & 1.88 & 0.04 \\
\hline ZEP2-DR06-03-L2 & 2.5 & 12.38 & 9.77 & 3484 & 10527 & 14623 & 3687 & 7774 & 1745 & 451 & 304 & 0.79 & 0.014 & 0.0036 & 0.0025 & 0.22 & 3.02 & 0.04 & 2.11 & 1.94 & 0.02 \\
\hline ZEP2-DR06-03-L3 & 4 & 12.46 & 9.96 & 3660 & 11517 & 14250 & 3575 & 7225 & 1777 & 483 & 317 & 0.80 & 0.014 & 0.0039 & 0.0025 & 0.25 & 3.15 & 0.04 & 2.01 & 1.86 & 0.04 \\
\hline ZEP2-DR06-03-L4 & 5.5 & 9.53 & 8.33 & 2764 & 8890 & 10726 & 2871 & 5385 & 1320 & 393 & 254 & 0.87 & 0.014 & 0.0041 & 0.0027 & 0.25 & 3.22 & 0.03 & 2.17 & 1.89 & 0.04 \\
\hline ZEP2-DR06-03-L5 & 7.5 & 7.72 & 10.09 & 3621 & 10999 & 11741 & 3278 & 3948 & 1011 & 420 & 328 & 1.31 & 0.013 & 0.0054 & 0.0042 & 0.26 & 3.04 & 0.04 & 3.24 & 1.84 & 0.03 \\
\hline ZEP2-DR06-03-L6 & 9.5 & 9.69 & 8.30 & 3794 & 7393 & 21139 & 3010 & 4907 & 1687 & 477 & 259 & 0.86 & 0.017 & 0.0049 & 0.0027 & 0.34 & 1.95 & 0.05 & 1.78 & 1.95 & 0.03 \\
\hline ZEP2-DR06-03-L7 & 11 & 8.56 & 7.78 & 4380 & 7062 & 21185 & 3347 & 3552 & 1279 & 480 & 239 & 0.91 & 0.015 & 0.0056 & 0.0028 & 0.36 & 1.61 & 0.06 & 2.62 & 1.89 & 0.03 \\
\hline ZEP2-DR06-03-L8 & 12.5 & 8.38 & 8.20 & 4312 & 7047 & 27977 & 3886 & 3952 & 1134 & 504 & 245 & 0.98 & 0.014 & 0.0060 & 0.0029 & 0.29 & 1.63 & 0.05 & 3.43 & 1.89 & 0.03 \\
\hline ZEP2-DR06-03-L9 & 14 & 8.36 & 8.52 & 4277 & 6783 & 48600 & 4067 & 4299 & 1146 & 557 & 258 & 1.02 & 0.014 & 0.0067 & 0.0031 & 0.27 & 1.59 & 0.05 & 3.55 & 1.87 & 0.03 \\
\hline ZEP2-DR06-03-L10 & 16 & 6.93 & 7.41 & 3743 & 5682 & 74906 & 5642 & 3551 & 972 & 492 & 230 & 1.07 & 0.014 & 0.0071 & 0.0033 & 0.27 & 1.52 & 0.05 & 5.81 & 1.80 & 0.03 \\
\hline ZEP2-DR06-03-L11 & 17.5 & 7.49 & 8.14 & 3948 & 6102 & 73244 & 8949 & 3954 & 1015 & 562 & 247 & 1.09 & 0.014 & 0.0075 & 0.0033 & 0.26 & 1.55 & 0.05 & 8.81 & 1.84 & 0.04 \\
\hline ZEP2-DR06-03-L12 & 19 & 6.96 & 7.03 & 3289 & 5546 & 71144 & 11887 & 3570 & 916 & 500 & 222 & 1.01 & 0.013 & 0.0072 & 0.0032 & 0.26 & 1.69 & 0.05 & 12.97 & 1.87 & 0.04 \\
\hline ZEP2-DR06-03-L13 & 21 & 6.82 & 7.46 & 3723 & 5554 & 95379 & 19236 & 3729 & 912 & 516 & 226 & 1.09 & 0.013 & 0.0076 & 0.0033 & 0.24 & 1.49 & 0.05 & 21.10 & 1.86 & 0.03 \\
\hline ZEP2-DR06-03-L14 & 23.5 & 6.27 & 6.40 & 3335 & 5062 & 118434 & 31536 & 3255 & 881 & 490 & 211 & 1.02 & 0.014 & 0.0078 & 0.0034 & 0.27 & 1.52 & 0.05 & 35.78 & 1.75 & 0.03 \\
\hline
\end{tabular}




\begin{tabular}{|c|c|c|c|c|c|c|c|c|c|c|c|c|c|c|c|c|c|c|c|c|c|}
\hline Sample name & $\begin{array}{l}\text { Depth in } \\
\text { the crust } \\
\text { (mm) }\end{array}$ & $\operatorname{Mn}(w t \%)$ & $\mathrm{Fe}(\mathrm{wt} \%)$ & Al $(\mu \mathrm{g} / \mathrm{g})$ & $\mathrm{Ti}(\mu \mathrm{g} / \mathrm{g})$ & $\mathrm{Ca}(\mu \mathrm{g} / \mathrm{g})$ & $P(\mu \mathrm{g} / \mathrm{g})$ & Co $(\mu \mathrm{g} / \mathrm{g})$ & $\mathrm{Ni}(\mu \mathrm{g} / \mathrm{g})$ & $\mathrm{Cu}(\mu \mathrm{g} / \mathrm{g})$ & $\mathrm{Zn}(\mu \mathrm{g} / \mathrm{g})$ & $\mathrm{Fe} / \mathrm{Mn}$ & $\mathrm{Ni} / \mathrm{Mn}$ & $\mathrm{Cu} / \mathrm{Mn}$ & $\mathrm{Zn} / \mathrm{Mn}$ & $\mathrm{Ni} / \mathrm{Co}$ & Ti/Al & $\mathrm{Al} / \mathrm{Fe}$ & $\mathrm{P} / \mathrm{Ni}$ & $\delta^{60 / 58} \mathrm{Ni}(\%)$ & 2 se $(\%)$ \\
\hline \multicolumn{22}{|l|}{ J2-480 Fe-Mn crust } \\
\hline Average & & 14.06 & 9.89 & 4097 & 7781 & 54630 & 24651 & 3045 & 2122 & 1124 & 574 & & & & & & & & & 1.65 & $0.19(2 s d)$ \\
\hline J2-480-R1 & 0.2 & 10.95 & 9.30 & 2794 & 10066 & 67980 & 32497 & 2749 & 730 & 663 & 582 & 0.85 & 0.007 & 0.0061 & 0.0053 & 0.48 & 3.60 & 0.03 & 44.51 & 1.72 & 0.07 \\
\hline J2-480-R2 & 2.5 & 11.23 & 7.80 & 1665 & 8039 & 47308 & 21279 & 2540 & 1629 & 843 & 465 & 0.69 & 0.014 & 0.0075 & 0.0041 & 0.94 & 4.83 & 0.02 & 13.07 & 1.74 & 0.03 \\
\hline J2-480-R3 & 5 & 9.91 & 7.10 & 1471 & 6220 & 31367 & 13294 & 2294 & 1355 & 795 & 458 & 0.72 & 0.014 & 0.0080 & 0.0046 & 0.97 & 4.23 & 0.02 & 9.81 & 1.65 & 0.07 \\
\hline J2-480-R4 & 7 & 14.87 & 9.59 & 2132 & 8925 & 45545 & 19196 & 4341 & 2118 & 1204 & 614 & 0.65 & 0.014 & 0.0081 & 0.0041 & 0.92 & 4.19 & 0.02 & 9.06 & 1.66 & 0.03 \\
\hline J2-480-R5 & 9 & 22.81 & 10.27 & 2176 & 8790 & 35156 & 11551 & 5574 & 3597 & 1837 & 761 & 0.45 & 0.016 & 0.0081 & 0.0033 & 0.95 & 4.04 & 0.02 & 3.21 & 1.67 & 0.04 \\
\hline J2-480-R6 & 11 & 19.83 & 11.55 & 2485 & 9252 & 69904 & 31549 & 4507 & 2814 & 1411 & 692 & 0.58 & 0.014 & 0.0071 & 0.0035 & 0.90 & 3.72 & 0.02 & 11.21 & 1.65 & 0.07 \\
\hline J2-480-R7 & 12.5 & 18.32 & 10.81 & 2829 & 9900 & 84690 & 39523 & 3709 & 2863 & 1331 & 709 & 0.59 & 0.016 & 0.0073 & 0.0039 & 0.90 & 3.50 & 0.03 & 13.81 & 1.72 & 0.05 \\
\hline J2-480-R8 & 14 & 17.21 & 9.84 & 2845 & 7906 & 61954 & 28104 & 2953 & 3001 & 1300 & 659 & 0.57 & 0.017 & 0.0076 & 0.0038 & 0.93 & 2.78 & 0.03 & 9.36 & 1.65 & 0.03 \\
\hline J2-480-R9 & 15 & 15.30 & 11.96 & 4224 & 7231 & 66488 & 30368 & 2809 & 2817 & 1310 & 644 & 0.78 & 0.018 & 0.0086 & 0.0042 & 0.94 & 1.71 & 0.04 & 10.78 & - & - \\
\hline J2-480-R10 & 16.5 & 8.01 & 11.54 & 9245 & 4765 & 59716 & 29250 & 1095 & 1225 & 888 & 432 & 1.44 & 0.015 & 0.0111 & 0.0054 & 0.95 & 0.52 & 0.08 & 23.88 & 1.64 & 0.04 \\
\hline J2-480-R12 & 19 & 6.16 & 9.03 & 13204 & 4499 & 30826 & 14550 & 917 & 1190 & 779 & 293 & 1.46 & 0.019 & 0.0126 & 0.0048 & 0.99 & 0.34 & 0.15 & 12.23 & 1.41 & 0.03 \\
\hline
\end{tabular}




\begin{tabular}{|c|c|c|c|c|c|c|c|c|c|c|c|c|c|c|c|c|c|c|c|c|c|}
\hline Sample name & $\begin{array}{l}\text { Depth in } \\
\text { the crust } \\
(\mathrm{mm})\end{array}$ & $\operatorname{Mn}(w t \%)$ & $\mathrm{Fe}(w t \%)$ & Al $(\mu \mathrm{g} / \mathrm{g})$ & $\mathrm{Ti}(\mu \mathrm{g} / \mathrm{g})$ & Ca $(\mu \mathrm{g} / \mathrm{g})$ & $P(\mu \mathrm{g} / \mathrm{g})$ & Co $(\mu \mathrm{g} / \mathrm{g})$ & $\mathrm{Ni}(\mu \mathrm{g} / \mathrm{g})$ & $\mathrm{Cu}(\mu \mathrm{g} / \mathrm{g})$ & $\mathrm{Zn}(\mu \mathrm{g} / \mathrm{g})$ & Fe/Mn & $\mathrm{Ni} / \mathrm{Mn}$ & $\mathrm{Cu} / \mathrm{Mn}$ & $\mathrm{Zn} / \mathrm{Mn}$ & $\mathrm{Ni} / \mathrm{Co}$ & Ti/Al & $\mathrm{A} / \mathrm{Fe}$ & $\mathrm{P} / \mathrm{Ni}$ & $\delta^{60158} \mathrm{Ni}(\%)$ & 2se $(\% \circ)$ \\
\hline \multicolumn{22}{|c|}{ J2-480-R14 Fe-Mn crust } \\
\hline Average & & 15.18 & 10.41 & 4341 & 7988 & 13325 & 2404 & 4749 & 3209 & 949 & 698 & & & & & & & & & 1.79 & $0.13(2 \mathrm{sd})$ \\
\hline J2-480-R14-L11 & 0.2 & 15.56 & 11.82 & 4952 & 9779 & 13237 & 2750 & 4691 & 3048 & 712 & 850 & 0.76 & 0.020 & 0.0046 & 0.0055 & 0.65 & 1.97 & 0.04 & 0.90 & 1.94 & 0.03 \\
\hline J2-480-R14-L10 & 3 & 12.95 & 10.73 & 5972 & 9719 & 11778 & 2376 & 3720 & 2554 & 707 & 945 & 0.83 & 0.020 & 0.0055 & 0.0073 & 0.69 & 1.63 & 0.06 & 0.93 & 1.81 & 0.03 \\
\hline J2-480-R14-L9 & 5 & 14.66 & 10.87 & 5936 & 10458 & 13635 & 2579 & 4707 & 3036 & 841 & 924 & 0.74 & 0.021 & 0.0057 & 0.0063 & 0.64 & 1.76 & 0.05 & 0.85 & 1.75 & 0.03 \\
\hline J2-480-R14-L8 & 7 & 17.31 & 10.36 & 6500 & 9819 & 13693 & 2661 & 5414 & 3325 & 911 & 630 & 0.60 & 0.019 & 0.0053 & 0.0036 & 0.61 & 1.51 & 0.06 & 0.80 & 1.78 & 0.04 \\
\hline J2-480-R14-L7 & 9 & 16.03 & 9.37 & 3441 & 9087 & 13503 & 2126 & 5977 & 3443 & 948 & 576 & 0.58 & 0.021 & 0.0059 & 0.0036 & 0.58 & 2.64 & 0.04 & 0.62 & 1.86 & 0.03 \\
\hline J2-480-R14-L6 & 10 & 17.38 & 9.71 & 2180 & 8542 & 14658 & 2378 & 6250 & 3819 & 1037 & 735 & 0.56 & 0.022 & 0.0060 & 0.0042 & 0.61 & 3.92 & 0.02 & 0.62 & 1.80 & 0.05 \\
\hline J2-480-R14-L5 & 12 & 13.74 & 10.53 & 2917 & 8317 & 13802 & 2330 & 5267 & 3156 & 1008 & 593 & 0.77 & 0.023 & 0.0073 & 0.0043 & 0.60 & 2.85 & 0.03 & 0.74 & 1.74 & 0.05 \\
\hline J2-480-R14-L4 & 14 & 16.40 & 10.00 & 2458 & 6755 & 14323 & 2118 & 5613 & 3447 & 1061 & 758 & 0.61 & 0.021 & 0.0065 & 0.0046 & 0.61 & 2.75 & 0.02 & 0.61 & 1.78 & 0.03 \\
\hline J2-480-R14-L3 & 16 & 18.51 & 11.76 & 3468 & 5845 & 14249 & 2523 & 4384 & 3680 & 1193 & 650 & 0.64 & 0.020 & 0.0064 & 0.0035 & 0.84 & 1.69 & 0.03 & 0.69 & 1.81 & 0.04 \\
\hline J2-480-R14-L2 & 18 & 13.18 & 10.44 & 4445 & 5020 & 12142 & 2261 & 3401 & 3048 & 1075 & 552 & 0.79 & 0.023 & 0.0082 & 0.0042 & 0.90 & 1.13 & 0.04 & 0.74 & 1.74 & 0.03 \\
\hline J2-480-R14-L1 & 20 & 11.23 & 8.96 & 5480 & 4522 & 11554 & 2340 & 2811 & 2737 & 950 & 471 & 0.80 & 0.024 & 0.0085 & 0.0042 & 0.97 & 0.83 & 0.06 & 0.85 & 1.70 & 0.03 \\
\hline Nod-P-1 & - & - & - & - & & - & & - & - & & - & - & & & & & & & & 0.34 & $0.04(2 \mathrm{sd})^{*}$ \\
\hline Nod-A-1 & - & - & - & - & & - & & - & - & - & - & - & - & - & - & & & & & 1.06 & $0.04(2 \mathrm{sd})$ \\
\hline
\end{tabular}

${ }^{\star} 2$ 2sd was caluclate on replicate measurements (see text for details). 
Table 2: ${ }^{10} \mathrm{Be} /{ }^{9} \mathrm{Be}$ ratios, ${ }^{9} \mathrm{Be}$ concentrations, Co/Mn ratios, age and growth rates of Fe-Mn crusts from North Pacific (Apuupuu) and South Pacific (Tahiti).

\begin{tabular}{|c|c|c|c|c|c|c|c|}
\hline Sample name & $\begin{array}{c}\text { Depth in the } \\
\text { crust (mm) }\end{array}$ & Co/Mn & ${ }^{9} \mathrm{Be}(\mu \mathrm{g} / \mathrm{g})$ & ${ }^{10} \mathrm{Be} /{ }^{9} \mathrm{Be}$ & $\operatorname{Age}^{*}(\mathrm{Ma})$ & $\begin{array}{c}\begin{array}{c}\text { Growth rate } \\
(\mathrm{mm} / \mathrm{Ma})\end{array} \\
\end{array}$ & Age (Ma) \\
\hline \multicolumn{8}{|c|}{ ZEP2-DR05-04 Fe-Mn crust } \\
\hline \begin{tabular}{|l|l} 
ZEP2-DR05-04-L1 \\
\end{tabular} & 0.5 & 0.073 & 2.6 & $1.02 \mathrm{E}-08$ & - & - & - \\
\hline ZEP2-DR05-04-L2 & 1 & 0.066 & 2.0 & na & - & - & - \\
\hline ZEP2-DR05-04-L3 & 2.5 & 0.054 & 2.6 & na & - & - & - \\
\hline ZEP2-DR05-04-L4 & 3.5 & 0.050 & 2.5 & na & - & - & - \\
\hline ZEP2-DR05-04-L5 & 4.5 & 0.041 & 1.9 & na & - & - & - \\
\hline ZEP2-DR05-04-L6 & 6.5 & 0.045 & 2.9 & 7.41E-09 & - & - & - \\
\hline ZEP2-DR05-04-L7 & 8.5 & 0.046 & 4.1 & na & - & - & - \\
\hline ZEP2-DR05-04-L8 & 10 & 0.049 & 3.4 & na & - & - & - \\
\hline ZEP2-DR05-04-L9 & 11.5 & 0.050 & 3.2 & na & - & - & - \\
\hline ZEP2-DR05-04-L10 & 12.5 & 0.055 & 2.9 & 6.50E-09 & - & - & - \\
\hline ZEP2-DR05-04-L11 & 13.5 & 0.052 & 2.6 & na & - & - & - \\
\hline ZEP2-DR05-04-L12 & 15.5 & 0.052 & 2.5 & na & - & - & - \\
\hline ZEP2-DR05-04-L13 & 16.5 & 0.050 & 2.2 & na & - & - & - \\
\hline ZEP2-DR05-04-L14 & 17.5 & 0.049 & 4.0 & $1.40 \mathrm{E}-07$ & 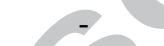 & - & - \\
\hline ZEP2-DR05-04-L15 & 19 & 0.042 & 2.2 & na & - & - & - \\
\hline ZEP2-DR05-04-L16 & 20 & 0.051 & 2.7 & na & - & - & - \\
\hline ZEP2-DR05-04-L17 & 22 & 0.050 & 1.4 & 4.31E-08 & - & - & - \\
\hline \multicolumn{8}{|l|}{ ZEP2-DR06-03 Fe-Mn crust } \\
\hline ZEP2-DR06-03-L1 & 0.5 & 0.076 & 2.0 & 6.91E-08 & 0.9 & - & 0.9 \\
\hline ZEP2-DR06-03-L2 & 2.5 & 0.063 & 3.0 & na & - & - & 2.1 \\
\hline ZEP2-DR06-03-L3 & 4 & 0.058 & 3.0 & na & - & - & 3.1 \\
\hline ZEP2-DR06-03-L4 & 5.5 & 0.057 & 2.6 & na & - & - & 4.0 \\
\hline ZEP2-DR06-03-L5 & 7.5 & 0.051 & 3.1 & 8.35E-09 & 5.2 & 1.45 & 5.2 \\
\hline ZEP2-DR06-03-L6 & 9.5 & 0.051 & 2.3 & na & & & 5.5 \\
\hline ZEP2-DR06-03-L7 & 11 & 0.042 & 2.3 & 6.07E-09 & 5.8 & 1.89 & 5.8 \\
\hline ZEP2-DR06-03-L8 & 12.5 & 0.047 & 2.6 & na & - & - & 5.9 \\
\hline ZEP2-DR06-03-L9 & 14 & 0.051 & 2.4 & na & - & - & 6.0 \\
\hline ZEP2-DR06-03-L10 & 16 & 0.051 & 2.2 & na & - & - & 6.0 \\
\hline ZEP2-DR06-03-L11 & 17.5 & 0.053 & 2.4 & 5.20E-09 & 6.1 & 2.86 & 6.1 \\
\hline ZEP2-DR06-03-L12 & 19 & 0.051 & 2.1 & na & & & 6.3 \\
\hline ZEP2-DR06-03-L13 & 21 & 0.055 & 2.2 & 4.28E-09 & 6.5 & 3.23 & 6.5 \\
\hline ZEP2-DR06-03-L14 & 23.5 & 0.052 & 2.2 & $3.51 \mathrm{E}-09$ & 6.9 & 3.40 & 6.9 \\
\hline \multicolumn{8}{|l|}{ J2-480 Fe-Mn crust } \\
\hline J2-480-R1 & 0.2 & 0.025 & 6.1 & 3.14E-09 & 7.1 & - & 7.1 \\
\hline $\mathrm{J} 2-480-\mathrm{R} 2$ & 2.5 & 0.023 & 4.6 & na & - & - & 7.4 \\
\hline J2-480-R3 & 5 & 0.023 & 4.3 & na & - & - & 7.7 \\
\hline J2-480-R4 & 7 & 0.029 & 5.3 & na & - & - & 7.9 \\
\hline $\mathrm{J} 2-480-\mathrm{R} 5$ & 9 & 0.024 & 4.8 & na & - & - & 8.2 \\
\hline J2-480-R6 & 11 & 0.023 & 5.7 & na & - & - & 8.4 \\
\hline $\mathrm{J} 2-480-\mathrm{R} 7$ & 12.5 & 0.020 & 6.1 & na & - & - & 8.6 \\
\hline J2-480-R8 & 14 & 0.017 & 5.3 & $1.40 \mathrm{E}-09$ & 8.7 & 1.60 & 8.7 \\
\hline $\mathrm{J} 2-480-\mathrm{R} 9$ & 15 & 0.018 & 6.2 & na & - & - & 9.4 \\
\hline$J 2-480-R 10$ & 16.5 & 0.014 & 6.1 & na & - & - & 10.4 \\
\hline $\mathrm{J} 2-480-\mathrm{R} 12$ & 19 & 0.015 & 4.7 & $2.71 \mathrm{E}-10$ & 12.0 & 1.58 & 12.0 \\
\hline \multicolumn{8}{|l|}{ J2-480-R14 Fe-Mn crust } \\
\hline J2-480-R14-L11 & 0.2 & 0.030 & 3.6 & $1.75 \mathrm{E}-08$ & 3.7 & - & 3.7 \\
\hline J2-480-R14-L10 & 3 & 0.029 & 3.7 & na & - & - & 5.5 \\
\hline J2-480-R14-L9 & 5 & 0.032 & 4.0 & 3.81E-09 & 6.7 & 0.74 & 6.7 \\
\hline J2-480-R14-L8 & 7 & 0.031 & 3.9 & na & - & - & 7.8 \\
\hline J2-480-R14-L7 & 9 & 0.037 & 3.5 & 1.32E-09 & 8.9 & 1.01 & 8.9 \\
\hline J2-480-R14-L6 & 10 & 0.036 & 3.6 & na & - & - & 9.4 \\
\hline J2-480-R14-L5 & 12 & 0.038 & 5.0 & na & - & - & 10.5 \\
\hline J2-480-R14-L4 & 14 & 0.034 & 4.0 & $3.53 \mathrm{E}-10$ & 11.5 & 1.22 & 11.5 \\
\hline J2-480-R14-L3 & 16 & 0.024 & 4.5 & na & - & - & 12.4 \\
\hline J2-480-R14-L2 & 18 & 0.026 & 3.9 & $1.50 \mathrm{E}-10$ & 13.2 & 1.36 & 13.2 \\
\hline J2-480-R14-L1 & 20 & 0.025 & 3.9 & $2.31 \mathrm{E}-11$ & 17.0 & 1.18 & 17.0 \\
\hline
\end{tabular}

*Derived from $\mathrm{Be}$ isotopes. 
ACCEPTED MANUSCRIPT
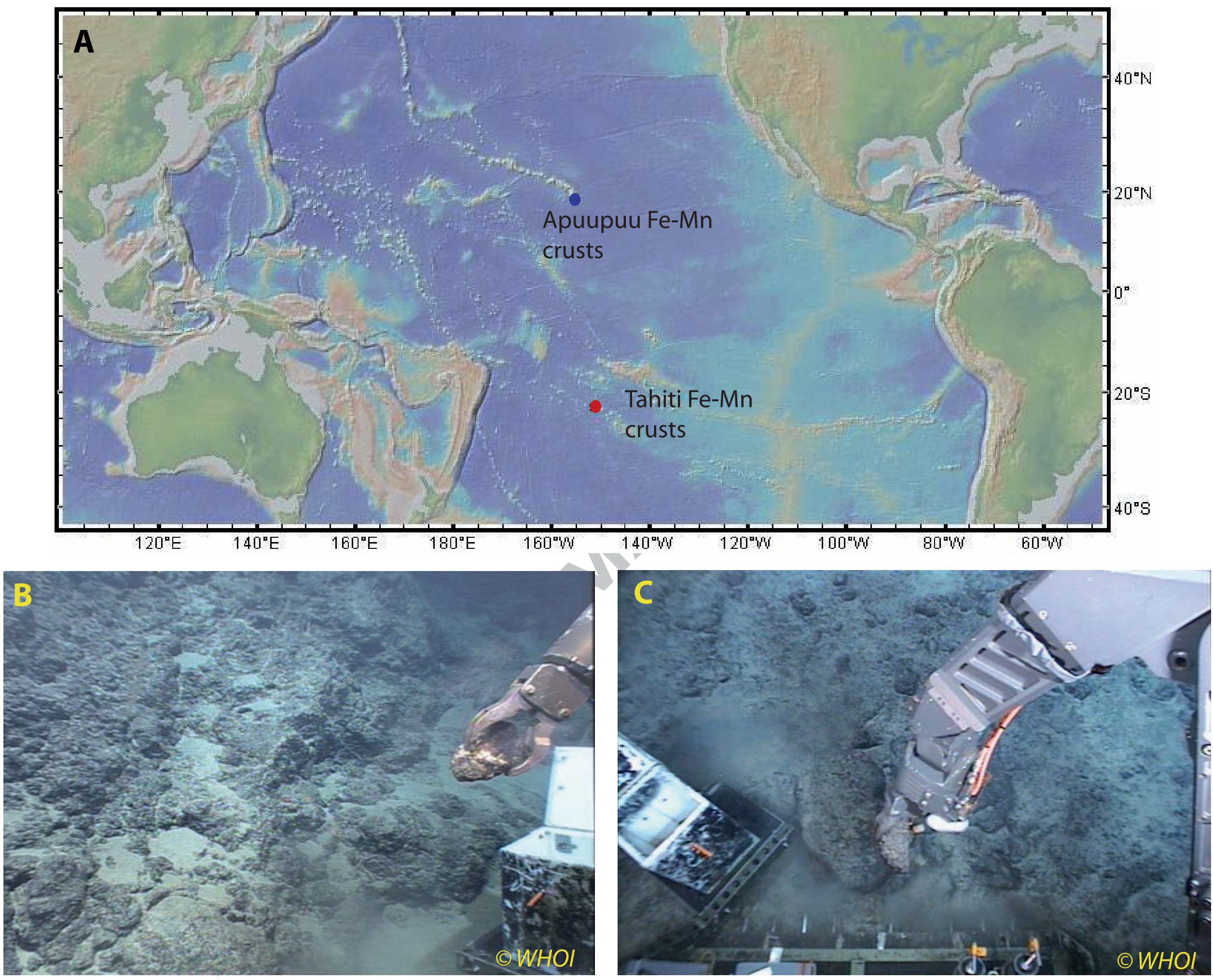

Figure 1 
(B) $\mathrm{J} 2-480$

Figure 2

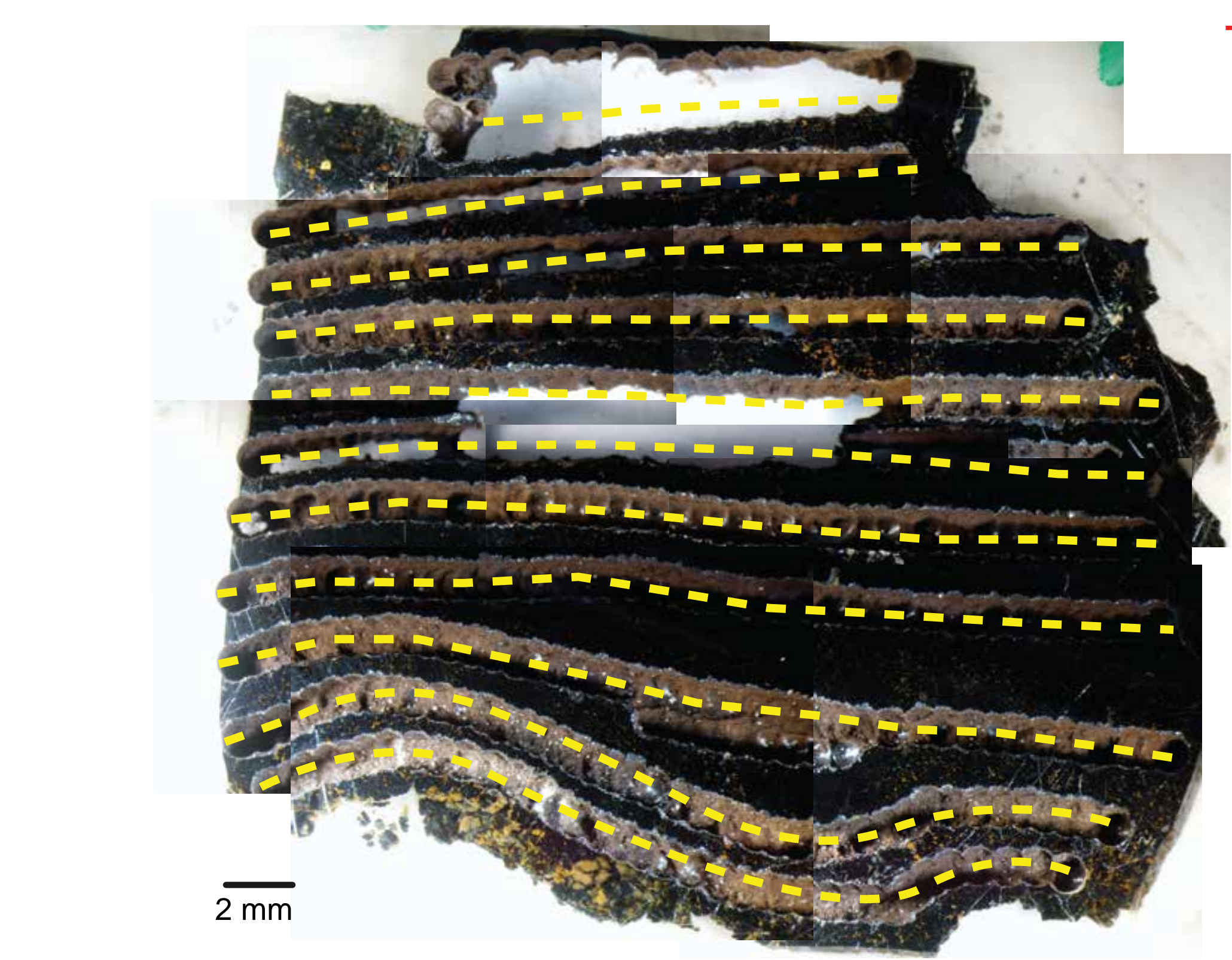

(C)

ZEP2-DR06-03

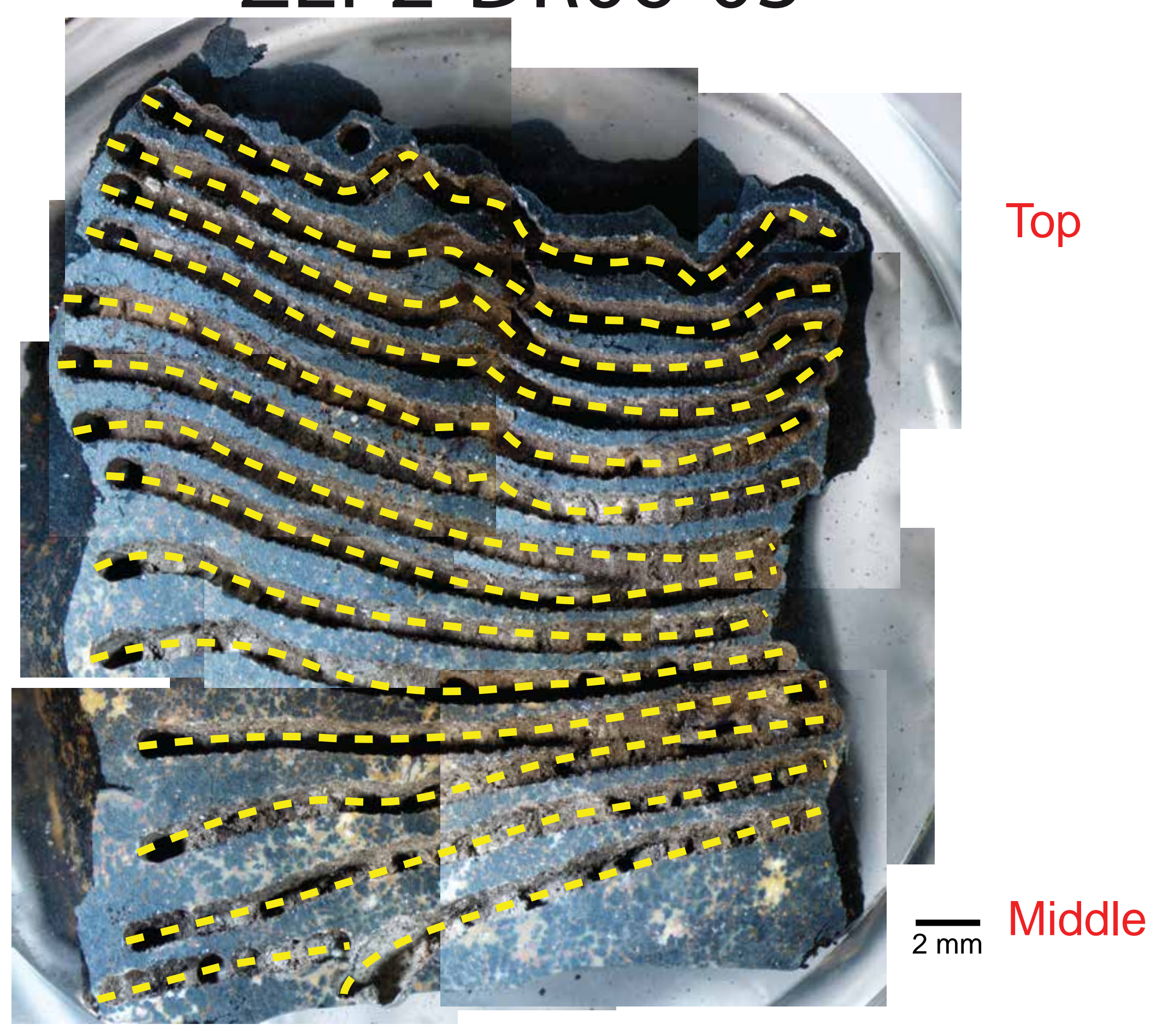

Middle

(D)

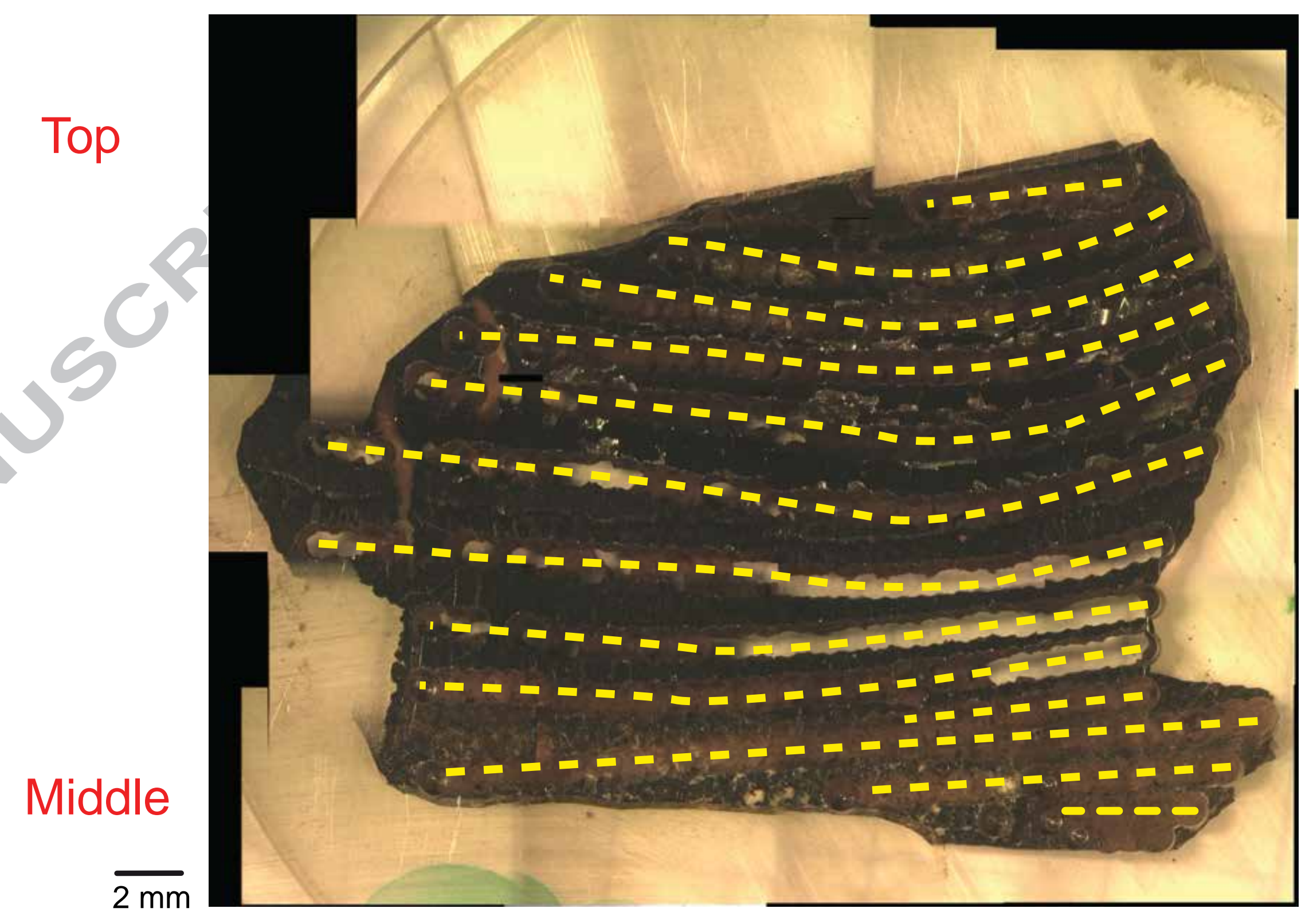

ZEP2-DR05-04

Top

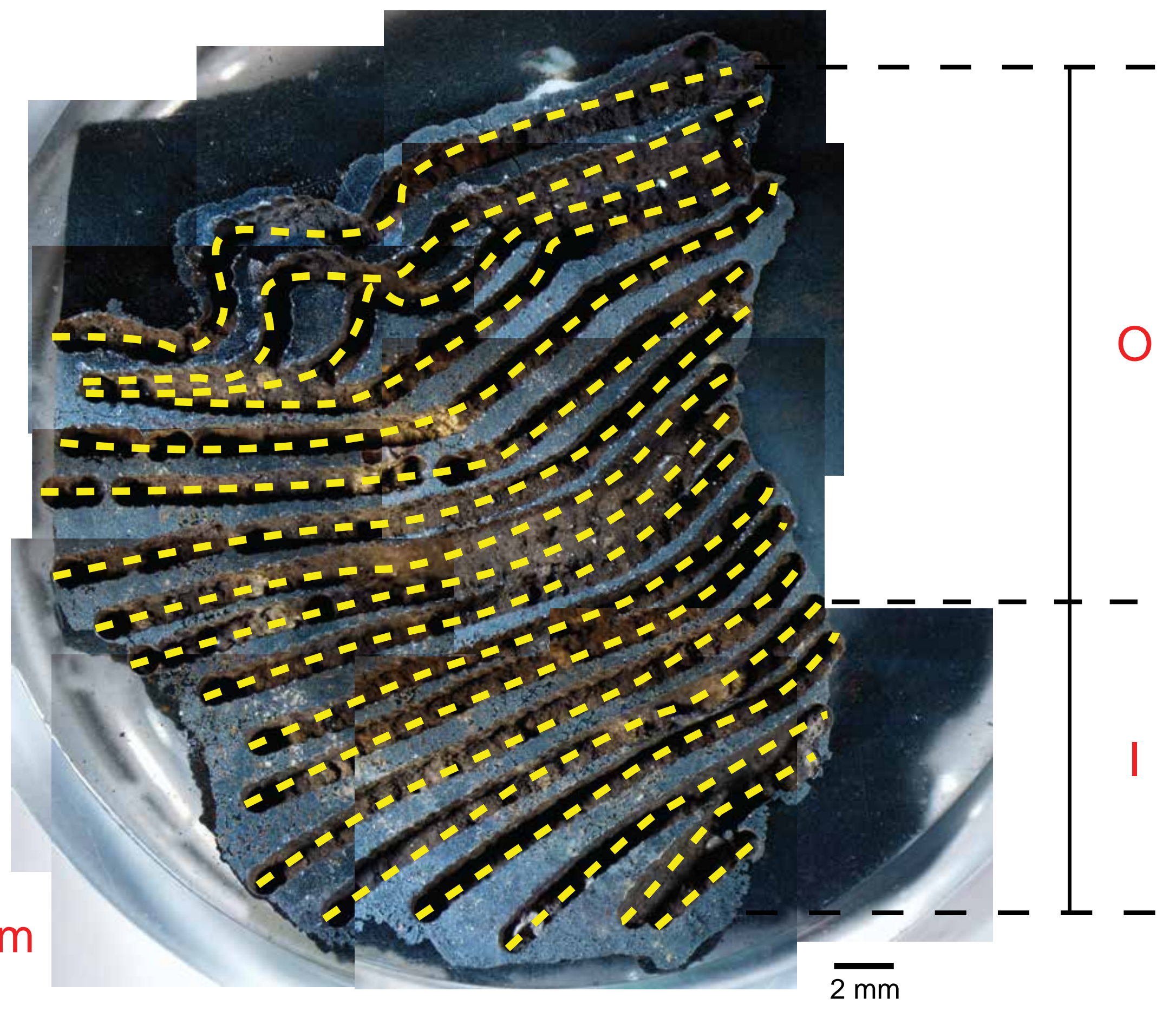




\section{ACCEPTED MANUSCRIPT}

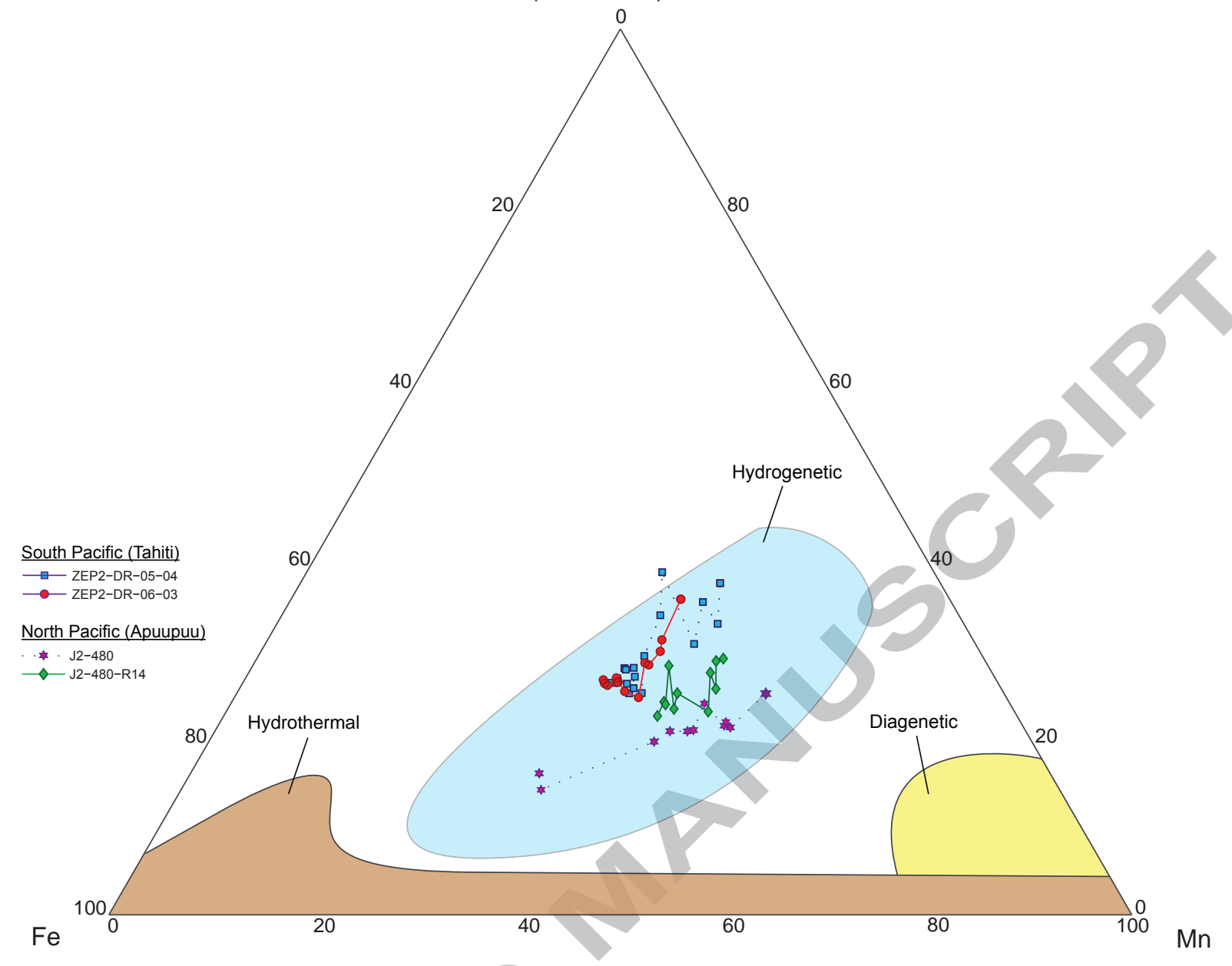

Figure 3 
South Pacific
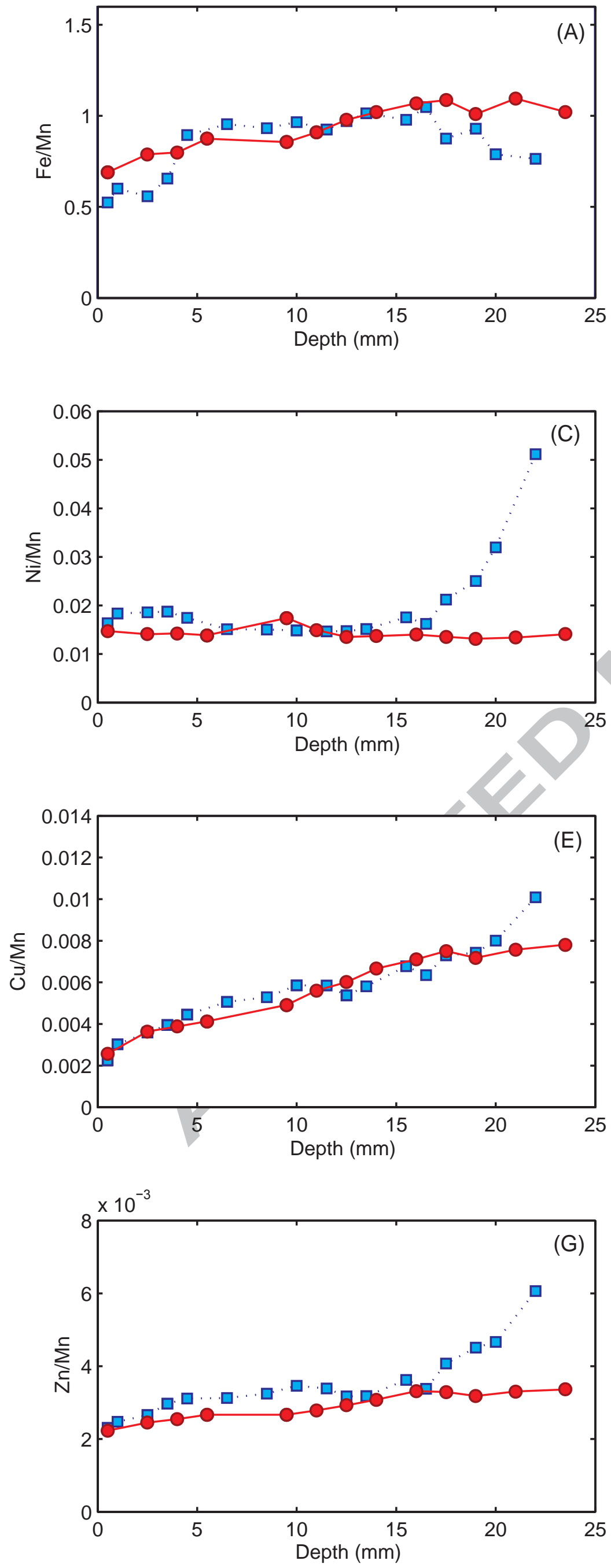

Figure 4
North Pacific
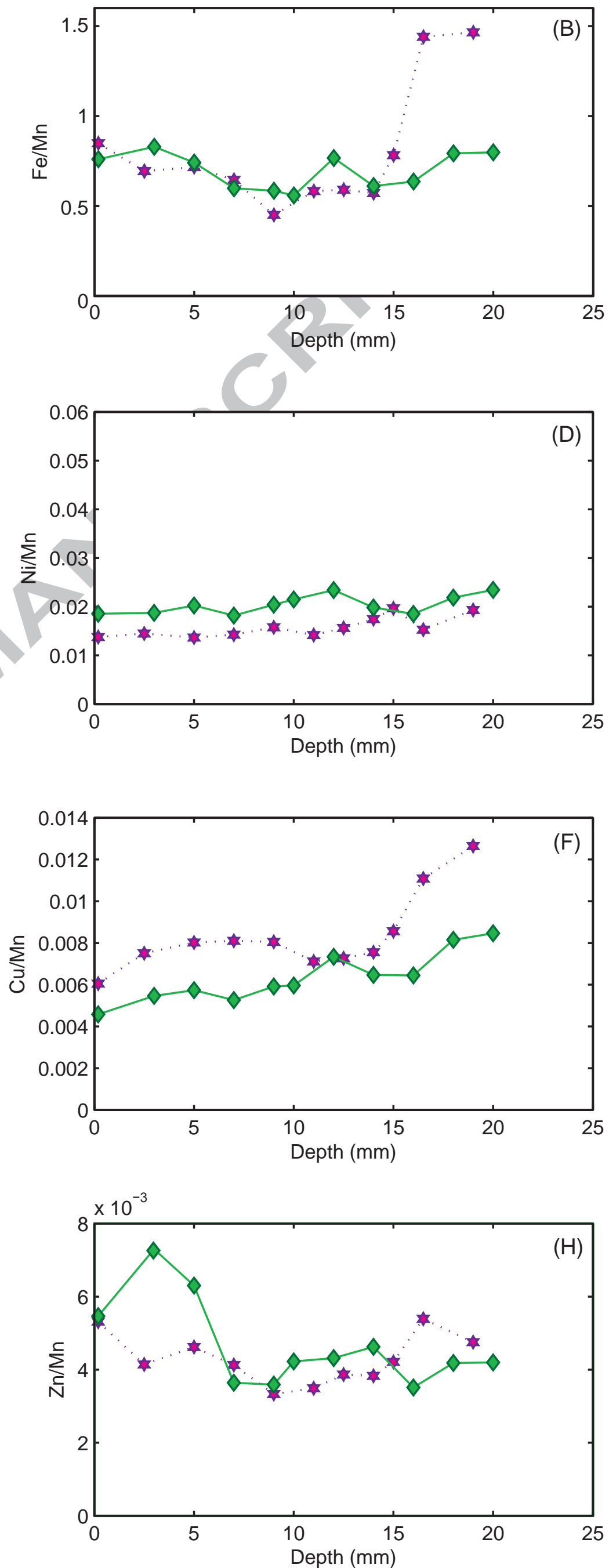
South Pacific
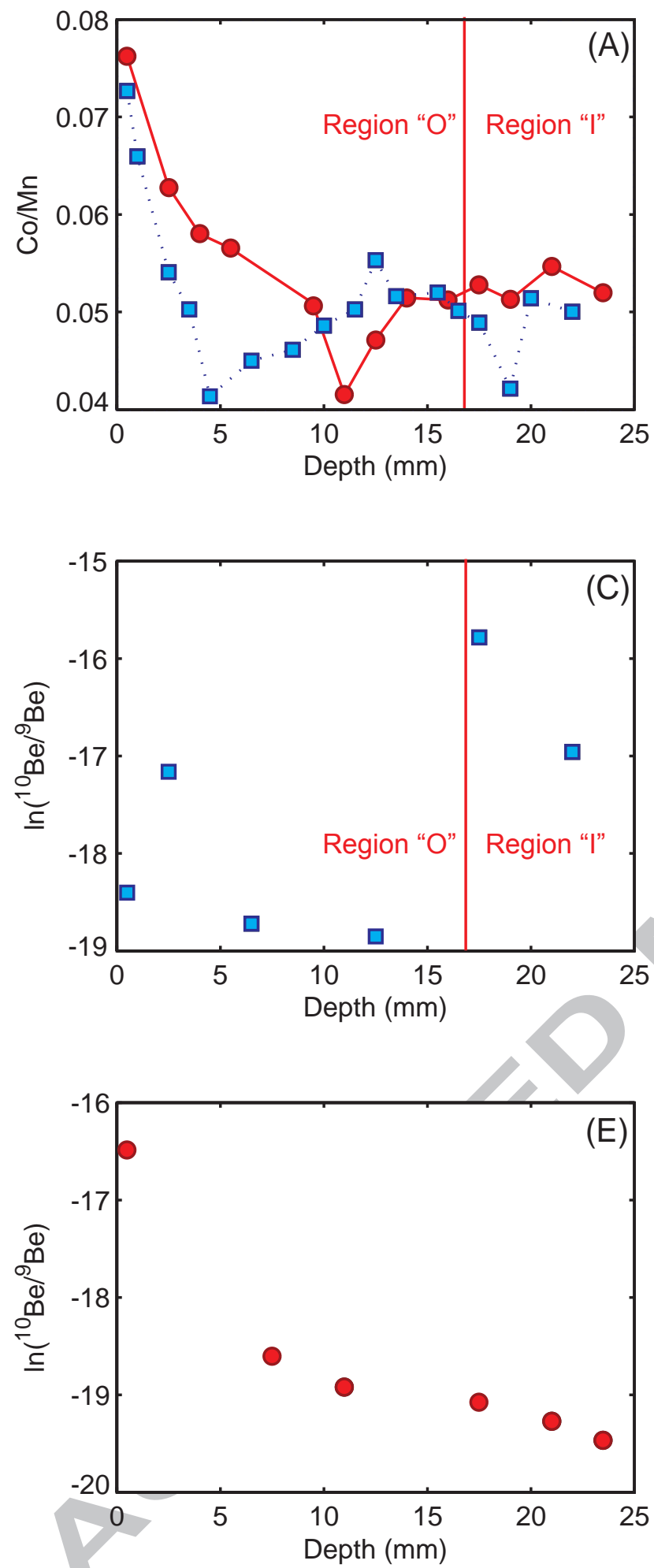

Figure 5
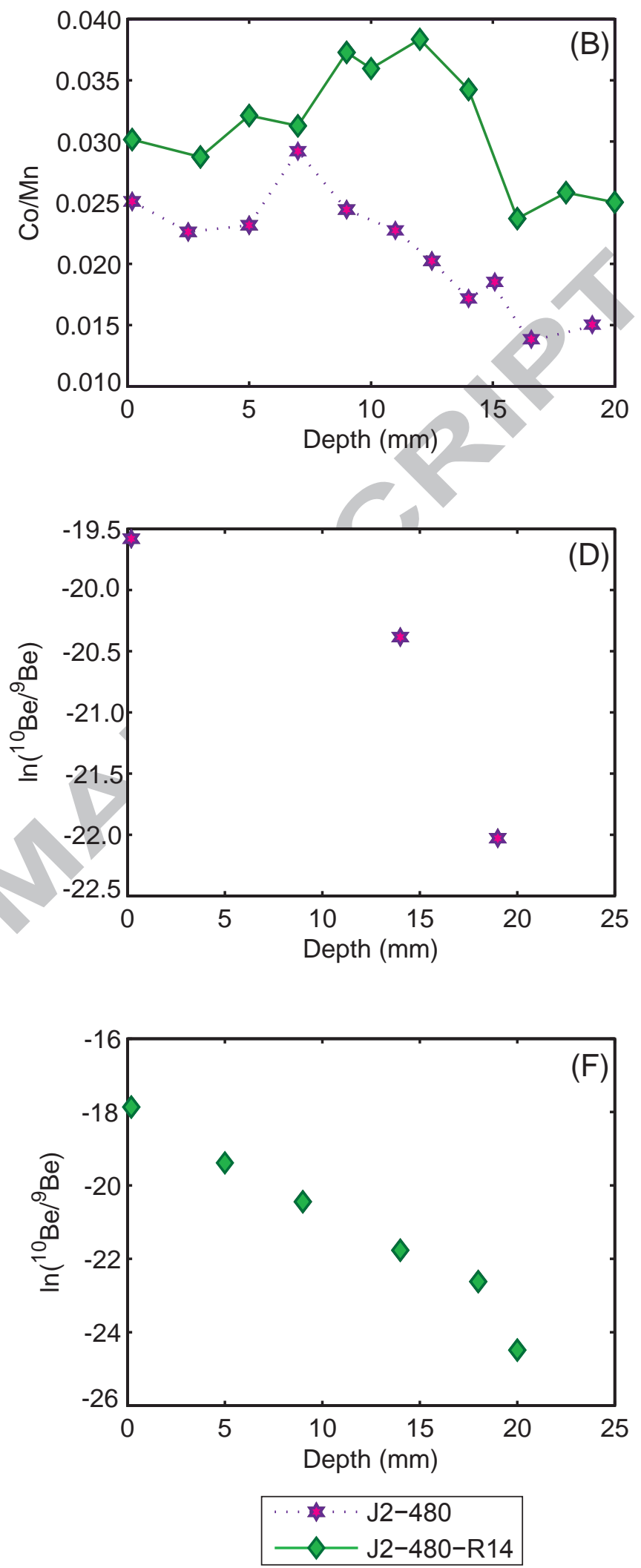


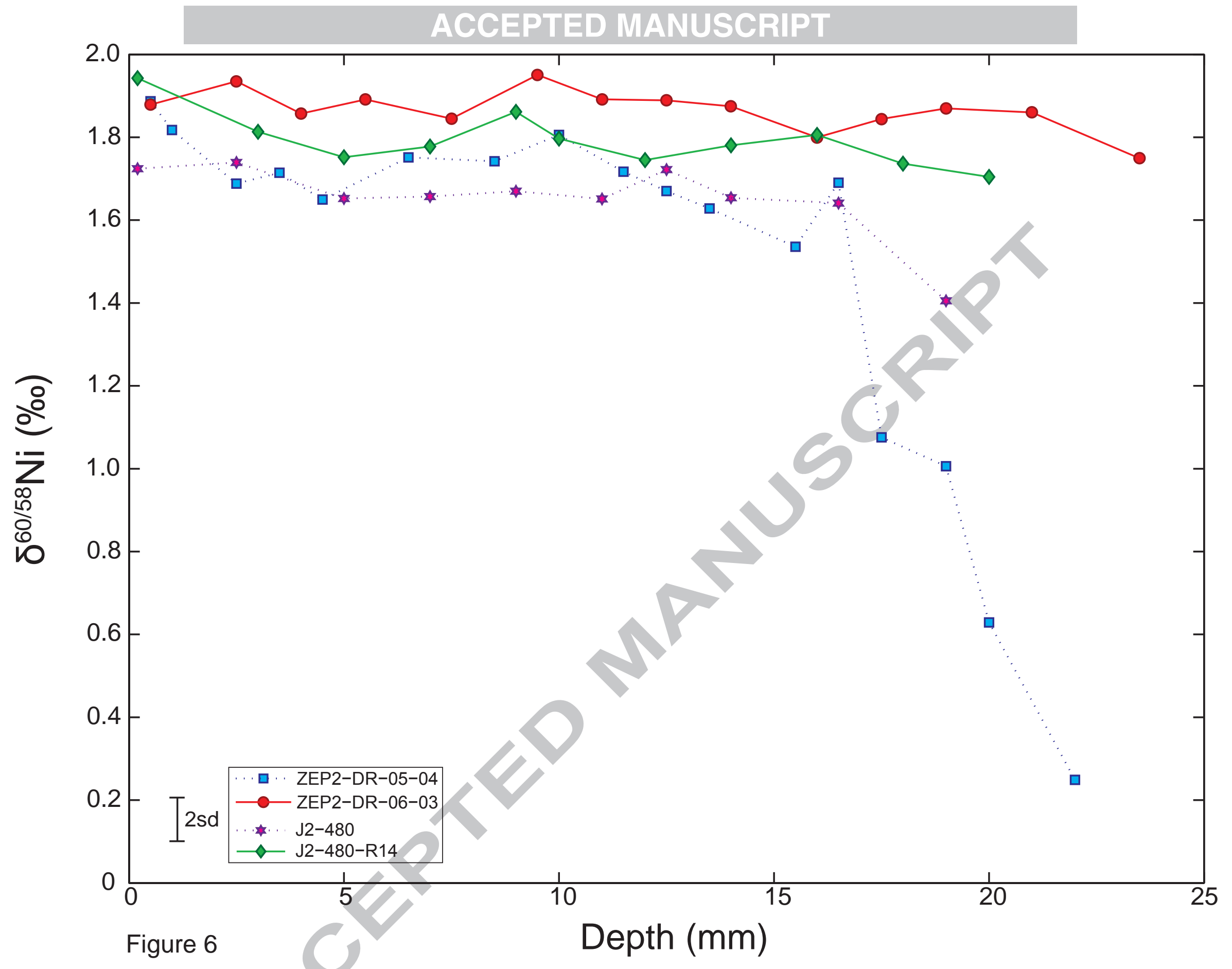



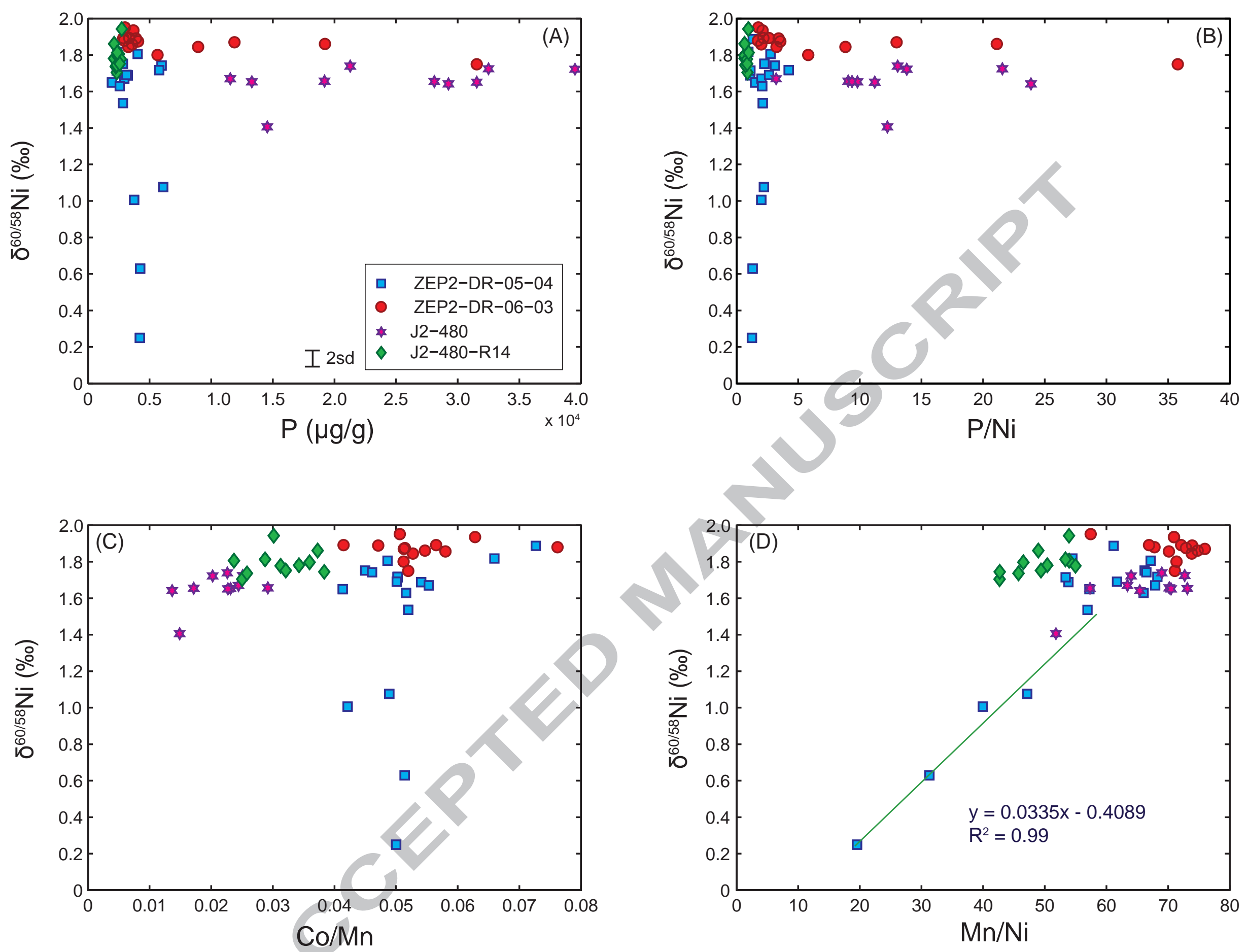

Figure 7 


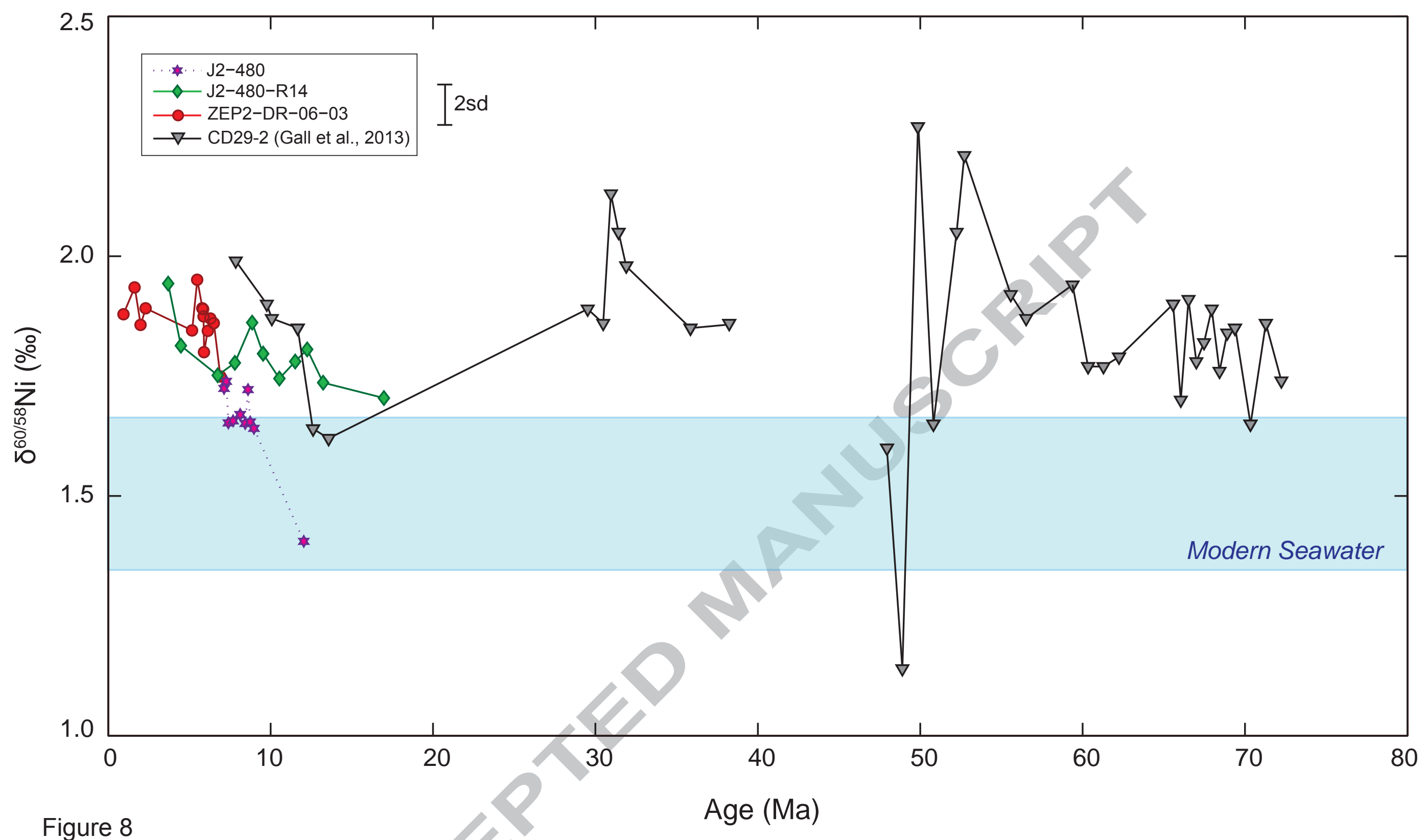

Figure 8

Age (Ma) 